\title{
Impacts of zinc oxide nano and bulk particles on redox-enzymes of the Punica granatum callus
}

\author{
Fatma A. Farghaly ${ }^{1}{ }^{1}$, Abeer A. Radi ${ }^{1}$, Fatma A. Al-Kahtany ${ }^{2}$ \& Afaf M. Hamada ${ }^{1 \bowtie}$
}

The structure and function of cellular membranes were sustained by redox-enzymes. We studied the interaction between the oxidative stress caused by excessive accumulation of $\mathrm{ZnO}$-nanoparticles (ZnO-NPs) in plants and the role of redox-enzymes that can alleviate this stress. The crude callus extract from pomegranate, which was treated with 0,10 , and $150 \mu \mathrm{g} \mathrm{m}^{-1} \mathrm{ZnO}-\mathrm{NPs}$ or bulk particles (ZnO-BPs), was applied to study the activity and kinetics of redox-enzymes. The elevated ZnO-NPs, enhanced the lipoxygenase and polyphenol oxidase activity, while the ZnO-BPs did not modify them. The activities of superoxide dismutase, catalase, and phenylalanine ammonia-lyase were induced under ZnO-NPs or BPs treatments, whilst the opposite trend of peroxidase was observed. Ascorbate peroxidase activity increased under ZnO-NPs treatments but decreased under ZnO-BPs. The kinetics activity of enzymes showed changes under different levels of NPs and BPs. Additionally, NPs or BPs treatments reduced the uptake of copper, iron, magnesium, but increased zinc accumulation in callus tissues. Meanwhile, these treatments enhanced the accumulation of manganese ions but did not affect the accumulation of potassium and phosphorous in ZnO-NPs or BPs-stressed calli. Collectively, these results gave a quantitative evaluation of the competition of zinc and other minerals on the carriers, and in addition, they provided a basis for how to control ZnO-NPs or BPs toxicity via redox-enzymes.

Nanotechnology has increased interest in many sciences, especially ZnO-NPs, which have received great attention due to their potential use in various sciences ${ }^{1}$. While there are broad fields of applications for ZnO-NPs, there is an interest in their release to ecosystems and their risks to resident organisms ${ }^{2,3}$. The release of $\mathrm{ZnO}-\mathrm{NPs}$ is potentially toxic to organisms and reaches the food chain. Cytological tests of $\mathrm{ZnO}-\mathrm{NPs}$ on pomegranate callus tissues showed that NPs reduced callus growth, dissociation of cytoplasmic content, and deformation of cell walls ${ }^{4}$.

In plants exposed to NPs, the uncontrolled output of reactive oxygen species (ROS) causes oxidative stress, which appears when the ROS level exceeds the defense mechanisms and is able to threaten cells by causing macromolecule damage and ultimately leads to cell death ${ }^{5}$. The size, surface area, and action of nanomaterials result in a high level of ROS that play a critical role in phytotoxic mechanisms ${ }^{6}$. Some researches on the environmental toxicity of NPs indicate the various potential mechanisms in which $\mathrm{ZnO}$-NPs have induced plant damage ${ }^{7,8}$. $\mathrm{ZnO}$-NPs induce LOX activity and membrane or DNA dysfunctions according to small volumes, large surface area, and ROS production ${ }^{9}$. Furthermore, the content of malondialdehyde (MDA) has been gradually increased with increasing levels of $\mathrm{ZnO}-\mathrm{NPs}$ in Cicer arietinum seedlings ${ }^{10}$ indicating the accumulation of MDA at high levels of cellular damage that may come out from $\mathrm{ROS}^{11}$.

Excess zinc accumulation, which reaches phytotoxic levels, induces physiological changes, and inhibits growth by causing membrane oxidation and reducing the intake of fundamental nutrients ${ }^{12}$. Excess $\mathrm{Zn}$ interferes with the root loading site and reduces the rate of translocation or absorption of essential plant nutrients or causes mineral imbalances ${ }^{13}$. Plants have generated defensive antioxidant systems to counteract the uncontrolled output of ROS $^{14}$. Antioxidants, non-enzymatic and enzymatic forms, prevent or suppress ROS reactions and delay or prevent cell damage ${ }^{15}$. Studies have shown that redox-enzymes can save cells from the harmful actions of $\operatorname{ROS}^{14,16,17}$. The phenylpropanoid biosynthesis pathway is stimulated under (a)biotic stressors that lead to the accumulation of various phenols that have the ability to break down harmful ROS $^{18}$. In plants, heavy metals activate the phenylpropanoid pathway by regulating the biosynthesis of key enzymes such as $\mathrm{PAL}^{19}$. Polyphenol oxidase also helps break down ROS and increases plant tolerance to abiotic stresses ${ }^{19,20}$. The mechanism of action of the redox-enzyme may rely on the concentrations of nanoparticles, plant species, nanoparticle types, and ecosystems ${ }^{21}$.

${ }^{1}$ Botany and Microbiology Department, Faculty of Science, Assiut University, Assiut 71516, Egypt. ${ }^{2}$ Biology Department, Faculty of Science, Ibb University, Ibb, Yemen. ${ }^{\circledR}$ email: hamada@aun.edu.eg 
Punica granatum L. (pomegranate) is an old fruit tree, known as a "Super-food", which has an extended history of medicinal uses as a herbal remedy for cancer, diarrhea, diabetes, blood pressure, leprosy, dysentery, bleeding, bronchitis, indigestion, and infections ${ }^{22}$. There are more than 1000 varieties, originating from the Middle East ${ }^{23}$, in Egypt, about 8080 hectares planted ${ }^{24}$ and an agricultural policy aimed at increasing production by expansion in reclaimed areas.

Despite numerous publications on plant tolerance mechanisms and antioxidant functions in plants exposed to heavy metals, woody plants have not been adequately studied in this area ${ }^{25}$. Moreover, the kinetics of the enzyme is important for assessing the function of the enzyme in the metabolic process. The tests aimed at enriching knowledge about $\mathrm{ZnO}$-NPs interactions with activity, the kinetics of redox-enzymes, and essential nutrients. Studies of pomegranate plants (woody plant) were performed in vitro conditions on callus tissue grown on MS medium with $\mathrm{ZnO}-\mathrm{NPs}$ compared to salt using $\mathrm{ZnO}$-BPs on redox-enzymes and essential minerals.

\section{Materials and methods}

ZnO-NPs and ZnO-BPs solutions. ZnO-NPs (99.5\% purity; particle size less than $100 \mathrm{~nm}$ and surface area $15-25 \mathrm{~m}^{2} \mathrm{~g}^{-1}$ ) were purchased from Sigma-Aldrich Company, St. Louis, MO, USA. ZnO-BPs used to be 99.999\% mineral powder. $\mathrm{ZnO}-\mathrm{NPs}$ and $\mathrm{ZnO}-\mathrm{BPs}$ were individually dissolved directly in distilled $\mathrm{H}_{2} \mathrm{O}$ and dispersed using ultrasonic vibration $(100 \mathrm{~W}, 40 \mathrm{kHz})$.

Tissue culture and treatments. Murashige \& Skoog media (MS) is composed of $4.4 \mathrm{~g} \mathrm{~L}^{-1} \mathrm{MS}, 3 \%$ sucrose, $6 \mathrm{mg}$ 2,4-D, $1 \mathrm{mg}$ AsA, $5 \mathrm{mg}$ adenine, $5 \mathrm{mg}$ casein, $10 \mathrm{mg}$ potassium dihydrogen phosphate, and different concentrations $\left(0,10\right.$, and $\left.150 \mu \mathrm{g} \mathrm{m}^{-1}\right)$ of pre-prepared $\mathrm{ZnO}-\mathrm{NPs}$ or $\mathrm{BPs}^{26}$. The $\mathrm{pH}$ was adjusted to 5.7 , then, $3 \mathrm{~g}$ $\mathrm{L}^{-1}$ gel-rite was added, sterilized at $121^{\circ} \mathrm{C}$ and a pressure of $105 \mathrm{kPa}$.

Fresh and healthy leaves were taken from pomegranate trees (Punica granatum cultivar Hegazy), washed under running tap water, and sterilized with $30 \% \mathrm{NaClO}^{27}$. The sterilized-leaves were soaked in $150 \mathrm{mg} \mathrm{L}^{-1} \mathrm{AsA}$ and $100 \mathrm{mg}$ citric acid for $20 \mathrm{~min}$ and washed with sterilized-water ${ }^{28}$. In a $195 \mathrm{~mL}$ jar, three sterile leaf pieces $(1-1.5 \mathrm{~cm})$ were transplanted into $30 \mathrm{~mL}$ of sterilized and solidified MS medium. These culture media were transferred to a growth chamber $\left(16 / 8 \mathrm{~h}\right.$, photoperiod $30 \mu \mathrm{M} \mathrm{m}^{-2} \mathrm{~S}^{-1}$ irradiance, temperature $25 \pm 1{ }^{\circ} \mathrm{C}$, relative humidity $50-60 \%)^{4}$. Some calli ( 4 weeks) were frozen in liquid nitrogen and stored at $-80^{\circ} \mathrm{C}$ for enzyme analysis, and the anther were dried at $60^{\circ} \mathrm{C}$ for $48 \mathrm{~h}$ for mineral identification. Twenty-five jars were applied in each treatment.

Enzyme extraction. The frozen callus $(0.5 \mathrm{~g})$ was ground to a fine powder in liquid nitrogen and homogenized in $5 \mathrm{~mL}$ of $100 \mathrm{mM}$ potassium phosphate buffer (PPB; pH 7.8) containing $0.1 \mathrm{mM}$ EDTA (ethylenediaminetetraacetic acid) and $0.1 \mathrm{~g}$ PVP (polyvinylpyrrolidone). The supernatants were used to test the activity and kinetics of the examined enzymes after centrifugation of the mixture $\left(4^{\circ} \mathrm{C}, 18,000 \mathrm{rpm}, 10 \mathrm{~min}\right)$. The protein content in the extract was estimated ${ }^{29}$.

Lipoxygenase (EC 1.13.11.12). LOX activity was tested following the technique of Minguez-Mosquera et al. ${ }^{30}$. To $5 \mathrm{~mL}$ of distilled $\mathrm{H}_{2} \mathrm{O}, 5 \mu \mathrm{L}$ of Tween- 20 and $35 \mu \mathrm{L}$ of linoleic acid were combined and the $\mathrm{pH}$ was adjusted to 9.0 using $200 \mathrm{mM} \mathrm{NaOH}$ until the mixture was clear. After the $\mathrm{pH}$ was adjusted to 6.5 by $\mathrm{HCl}$, the total volume was adjusted to $100 \mathrm{~mL}$ by $100 \mathrm{mM}$ PPB. Absorption was tested after $50 \mu \mathrm{L}$ of enzyme aliquots were incorporated into the reaction medium $(2.95 \mathrm{~mL})$. The alteration in absorbance per unit protein within $1 \mathrm{~min}$ $\left(\mathrm{DA}_{234} \mathrm{mg}\right.$ protein $\left.{ }^{-1} \mathrm{~min}^{-1}\right)$ was measured as an activity.

Superoxide dismutase (EC 1.15.1.1). SOD activity was tested after epinephrine oxidation ${ }^{31}$. The substrate mixture $(3 \mathrm{~mL})$ included $\mathrm{Na}_{2} \mathrm{CO}_{3}$ buffer $(0.05 \mathrm{M}$; $\mathrm{pH} 10.2), 0.1 \mathrm{~mL}$ EDTA, $0.05 \mathrm{~mL}$ enzyme aliquot and $100 \mu \mathrm{L}$ epinephrine. The alteration in absorption per unit protein within $1 \mathrm{~min}$ was measured at $480 \mathrm{~nm}\left(\mathrm{DA}_{480}\right.$ $\mathrm{mg} \operatorname{protein}^{-1} \mathrm{~min}^{-1}$ ) as an activity.

Catalase (EC 1.11.1.6). CAT activity was examined one minute after $\mathrm{H}_{2} \mathrm{O}_{2}$ consumption ${ }^{32}$. The reaction method included $50 \mathrm{mM}$ PPB ( $\mathrm{pH}$ 7), $100 \mu \mathrm{L} \mathrm{H}_{2} \mathrm{O}_{2}(10 \mathrm{mM})$, and a $20 \mu \mathrm{L}$ enzyme aliquot. Absorbance was examined and the difference in absorbance per unit protein within $1 \mathrm{~min}\left(\mathrm{DA}_{240} \mathrm{mg}\right.$ protein $\left.{ }^{-1} \mathrm{~min}^{-1}\right)$ was measured as an activity.

Peroxidase (EC 1.11.1.7). POD activity was examined after tetraguaiacol formation ${ }^{33}$. The assay medium included PPB (30 mM, pH 7), hydrogen peroxide $(6.5 \mathrm{mM})$, guaiacol $(1.5 \mathrm{mM})$, and an enzyme aliquot (100 $\mu \mathrm{L})$. Absorbance was examined and the difference in absorbance per unit protein within 1 min $\left(\mathrm{DA}_{470} \mathrm{mg}\right.$ protein ${ }^{-1} \mathrm{~min}^{-1}$ ) was measured as an activity.

Ascorbate peroxidase (EC 1.11.1.11). The activity of APX was examined after AsA oxidation ${ }^{34}$. The reaction medium contained PPB pH $7.0(50 \mathrm{mM})$, ETDA $(0.1 \mathrm{mM})$, hydrogen peroxide $(1.2 \mathrm{mM})$, AsA $(0.5 \mathrm{mM})$, and an enzyme aliquot $(50 \mu \mathrm{L})$. The absorbance was examined and the change in the absorbance per unit protein within $1 \mathrm{~min}\left(\mathrm{DA}_{290} \mathrm{mg}\right.$ protein $\left.{ }^{-1} \mathrm{~min}^{-1}\right)$ was measured as an activity.

Phenylalanine ammonia-lyase (EC 4.3.1.5). PAL activity was bio-assayed after trans-cinemate production ${ }^{35}$. The experiment medium $(2 \mathrm{~mL})$ consisted of $50 \mathrm{mM}$ borate buffer ( $\left.\mathrm{pH} 8.7\right), 1 \mathrm{mg} \mathrm{L}^{-1}$ phenylalanine, $0.5 \mathrm{~mL}$ enzyme aliquot, and was left for one hour at $37^{\circ} \mathrm{C}$. The absorbance was checked after the termina- 

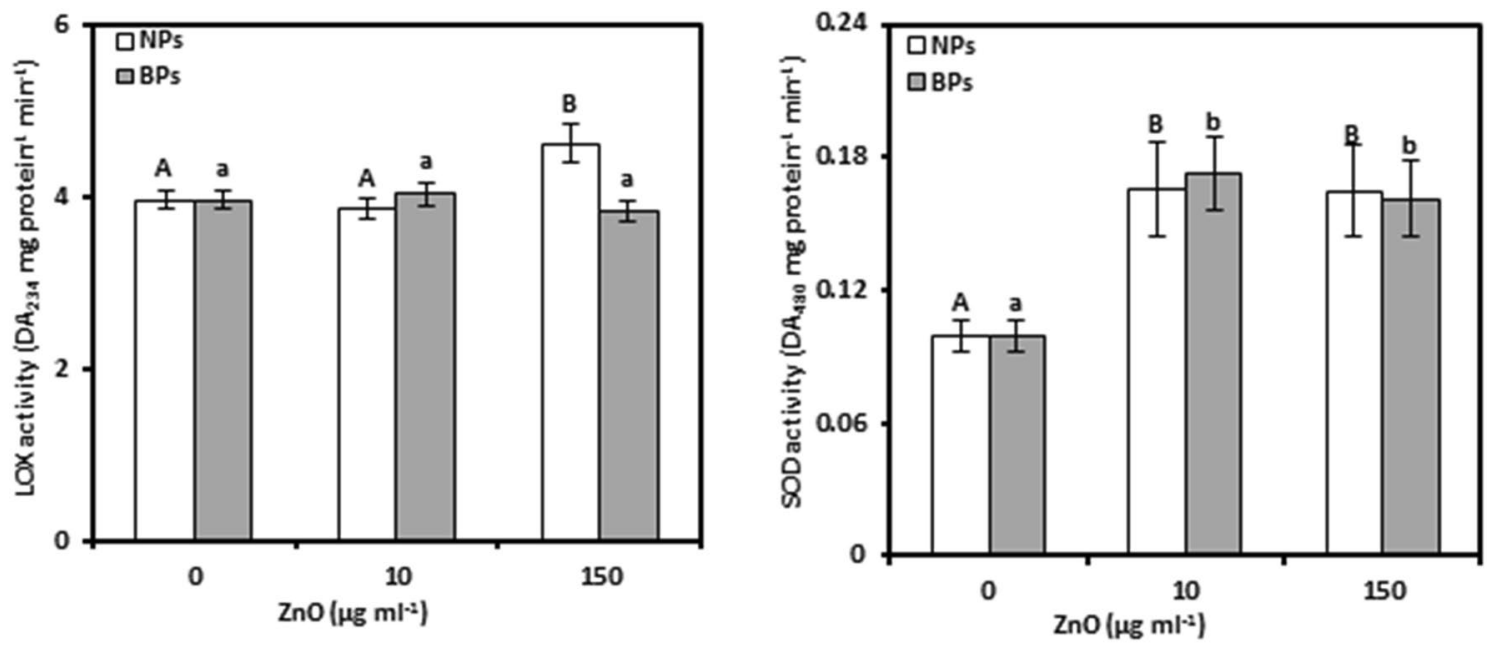

Figure 1. Lipoxygenase (LOX; a) and superoxide dismutase (SOD; b) activity of Punica granatum calli under the influence of different concentrations of $\mathrm{ZnO}-\mathrm{NPs}$ and BPs for 28 days. Data are means $\pm \mathrm{SD}(\mathrm{n}=4)$. The different letters, capital for NPs treatments and small for BPs, indicate statistically significant differences $(P \leq 0.05)$.

tion of the reaction with $1 \mathrm{~mL}$ of $\mathrm{HCl}(0.5 \mathrm{~N})$ and centrifugation $(5 \mathrm{~min}, 2000 \mathrm{rpm})$. The change in absorption per unit protein within $1 \mathrm{~min}\left(\mathrm{DA}_{290} \mathrm{mg}\right.$ protein $\left.{ }^{-1} \mathrm{~min}^{-1}\right)$ was measured as an activity.

Polyphenol oxidase (EC1.14.18.1). The activity of PPO was tested after the production of purpurogallin ${ }^{36}$. The mixture medium $(2 \mathrm{~mL})$ consisted of $100 \mathrm{mM}$ PPB (pH 6), $1 \mathrm{~mL}$ catechol $(100 \mathrm{mM})$, enzyme aliquot $(200 \mu \mathrm{L})$, and was left at $25^{\circ} \mathrm{C}(5 \mathrm{~min})$. The absorbance was monitored at $495 \mathrm{~nm}$ after the termination of the reaction with $1 \mathrm{~mL}$ of $\mathrm{H}_{2} \mathrm{SO}_{4}(2.5 \mathrm{~N})$. The alteration in absorbance per unit protein within $1 \mathrm{~min}\left(\mathrm{DA}_{495} \mathrm{mg}\right.$ protein ${ }^{-1} \mathrm{~min}^{-1}$ ) was measured as an activity.

Kinetic parameters. The kinetic activities of all tested enzymes were studied using different levels of enzyme aliquot and data plotted as $1 / \mathrm{V}$ and $1 / \mathrm{S}^{37}$. Michaelis constant $\left(\mathrm{K}_{\mathrm{m}}\right)$, maximum velocity $\left(\mathrm{V}_{\max }\right)$, catalytic rate constant $\left(\mathrm{K}_{\mathrm{cat}}\right)$ values were evaluated by Michaelis-Menten plots.

Minerals. Dry callus tissues were digested by perchloric acid (60\%), nitric acid (Analar), and sulfuric acid (Analar) in a 1:3:1 ratio for the assay copper, iron, potassium, magnesium, manganese, phosphorous, and zinc ${ }^{4}$. Potassium and $\mathrm{P}$ were assayed in the digested samples ${ }^{4}$ and were expressed as $\mathrm{mg} \mathrm{g}^{-1}$ dry weight (DW). Other minerals $(\mathrm{Cu}, \mathrm{Fe}, \mathrm{Mg}, \mathrm{Mn}$, and $\mathrm{Zn}$ ) were measured using atomic absorption spectrophotometry (Buck's $210 \mathrm{Vgp}$ model, USA) and were expressed as $\mathrm{mg} \mathrm{g}^{-1} \mathrm{DW}$.

Statistical analysis. Present values ( \pm standard deviation) have been averages of four biological replicates, with all three technical replicates, in most cases, and analysis was performed by SPSS software (version 22). One-way test (ANOVA) and Tukey's test were performed for multiple comparisons $(P \leq 0.05)$. Correlation tests (Pearson correlation) were carried to achieve the relation between the mean rate of various criteria of pomegranate under $\mathrm{ZnO}-\mathrm{NPs}$ and BPs. Asterisks indicate a significant correlation ( ${ }^{*}$ and ${ }^{\star *}$ at 5 and $1 \%$, respectively). Correspondence analysis was used to analyze relationships between redox-enzyme activities or mineral concentrations and different concentrations of $\mathrm{ZnO}$ particles.

\section{Results}

Lipoxygenase. The activities of LOXs were assessed in pomegranate calli exposed to different levels of $\mathrm{ZnO}-\mathrm{NPs}$ or BPs to consider the degree of membrane damage (Fig. 1a, Tables S1, 2). The data showed that ZnONPs at the low level failed to significantly enhance LOX activity, while the high level promoted such activity by about $17 \%$, compared to the controls. However, the different levels of $\mathrm{ZnO}$-BPs did not considerably alter LOX activity. $\mathrm{ZnO}-\mathrm{NPs}$ showed a significant correlation between LOX activity $\left(0.857^{\star *}\right)$ and $\mathrm{Zn}$ content, whereas in the case of BPs this relationship was insignificant $(-0.552)$.

Superoxide dismutase. SOD activity was assessed as an important scavenger for ROS (Fig. 1b, Tables S1, and S2). In pomegranate calli, SOD activity was induced by increased levels of ZnO-NPs or BPs in the nutrient medium. Compared to untreated controls at treatments of 10 and $150 \mu \mathrm{g} \mathrm{mL}^{-1}$, the elevation was 66.45 and 65.31\% in NPs and 72.98 and $61.71 \%$ in BPs, respectively. Moreover, in the case of NPs, the correlation between SOD activity and $\mathrm{Zn}$ concentration was significant $\left(0.710^{\star}\right)$, while it was insignificant $(0.448)$ in the BPs. 

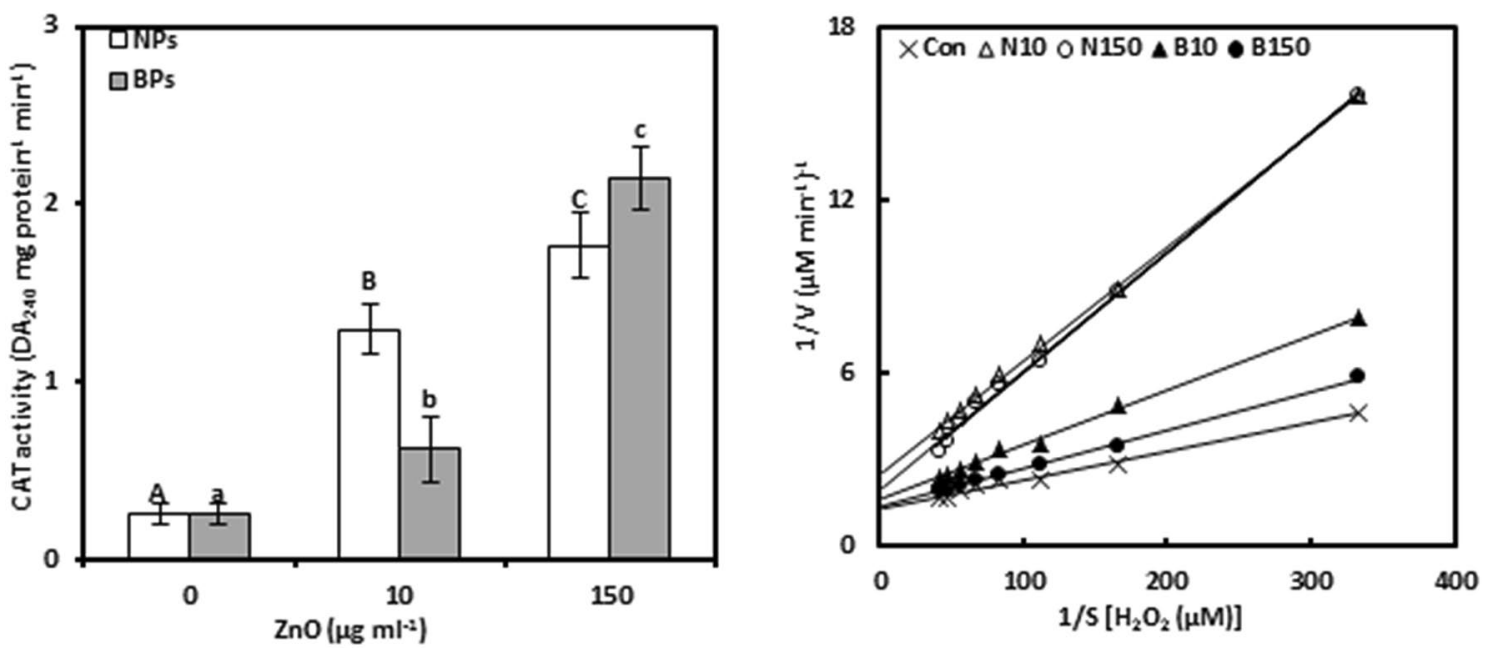

Figure 2. Catalase activity (CAT; a) and Lineweaver-Burk curve of CAT enzyme (b) of Punica granatum calli under the influence of different concentrations of $\mathrm{ZnO}-\mathrm{NPs}$ and BPs for 28 days. Data are means \pm SD $(\mathrm{n}=4)$. The different letters, capital for NPs treatments and small for BPs, indicate statistically significant differences $(P \leq 0.05)$.

Catalase. CAT activity was evaluated in pomegranate calli exposed to different levels of NPs or BPs because it helps in dismutation $\mathrm{H}_{2} \mathrm{O}_{2}$ into $\mathrm{H}_{2} \mathrm{O}$ and $\mathrm{O}_{2}$ (Fig. 2a, Tables S1, 2). CAT activity was stimulated with increased levels of $\mathrm{ZnO}-\mathrm{NPs}$ or BPs, with the highest concentration of $\mathrm{ZnO}$-BPs $\left(150 \mu \mathrm{gL}^{-1}\right)$ showing an 8.34 -fold higher increase in CAT activity compared to ZnO-NPs which resulted in 6.87-fold over the non-treated-control. Additionally, the result showed that CAT activity in the case of NPs $\left(0.835^{\star *}\right)$ and BPs $\left(0.989^{\star *}\right)$ represented significant correlations with zinc contents in callus tissues.

Furthermore, various assays were performed to test kinetic activity with respect to the CAT enzyme under different concentrations of ZnO-NPs or ZnO-BPs (Fig. 2b, Table 1, Tables S3, 4). An increase in NPs or BPs treatments led to a catalytic effect on $\mathrm{K}_{\mathrm{m}}$ of CAT. For example, in the low and high treatments of NPs or BPs, the $\mathrm{K}_{\mathrm{m}}$ increased to $105.93,246.59,50.54$, and $30.19 \%$, respectively; higher than the control. Additionally, the NPs showed a significant correlation between the $\mathrm{K}_{\mathrm{m}}$ and the $\mathrm{Zn}$ content $\left(0.963^{\star *}\right)$, however, this relationship in the case of BPs was minimal (0.245).

NPs or BPs treatments reduced $V_{\max }$ of the CAT enzyme by $46.61,15.74,19.15$ and $2.93 \%$, respectively, compared to the control. However, the correlation between $\mathrm{V}_{\max }$ and $\mathrm{Zn}$ in the NPs or BPs treated callus was insignificant.

The $\mathrm{K}_{\text {cat }}$ rate of CAT was increased in NPs or BPs-treated calli, only $10 \mu \mathrm{g} \mathrm{mL}^{-1} \mathrm{NPs}$ decreased it slightly. The high level of NPs or BPs $\left(150 \mu \mathrm{g} \mathrm{mL}^{-1}\right)$ stimulated $\mathrm{K}_{\text {cat }}$ by 36.73 and $33.06 \%$, respectively, over the controls. Moreover, NPs and BPs treatments showed a marked positive association between $\mathrm{K}_{\mathrm{cat}}$ and $\mathrm{Zn}$ content $\left(0.948^{\star *}\right.$ and $0.711^{*}$, respectively).

Peroxidase. POD activity was evaluated as it stimulates the oxidation by $\mathrm{H}_{2} \mathrm{O}_{2}$ of a broad range of organic (Fig. 3a, Tables S1, 2). Treatments of pomegranate calli with ZnO-NPs or BPs negatively affected POD activity. The decrease in activity at $150 \mu \mathrm{g} \mathrm{mL}^{-1}$ of $\mathrm{ZnO}$-NPs or BPs treatments, compared to the controls, was 61.07 and $67.12 \%$, respectively. As expected, $\mathrm{ZnO}-\mathrm{NPs}$ or BPs treatments showed negative relationships between POD activity and $\mathrm{Zn}$ concentrations $\left(-0.663\right.$ and $-0.794^{\star}$, respectively).

For POD kinetic activity, ZnO-NPs or BPs treatments reduced the $\mathrm{K}_{\mathrm{m}}$ and $\mathrm{V}_{\max }$, with $\mathrm{K}_{\mathrm{m}}$ only slightly stimulated by $10 \mu \mathrm{g} \mathrm{mL}^{-1}$ BPs (Fig. 3b, Table 1, Tables S5 6). Compared with control calli, $10 \mu \mathrm{g} \mathrm{mL} \mathrm{m}^{-1}$ treatments of $\mathrm{ZnO}-\mathrm{NPs}$ or $\mathrm{ZnO}-\mathrm{BPs}$ showed a higher decrease in $\mathrm{K}_{\mathrm{m}}$ and $\mathrm{V}_{\max }$, compared to $150 \mu \mathrm{g} \mathrm{mL} \mathrm{g}^{-1}$, which caused reductions of $40.10 \%, 25.73 \%, 16.09 \%$, and $10.23 \%$, respectively. In other words, the increased concentration of NPs or BPs caused a stimulating effect on $\mathrm{K}_{\text {cat }}$, only $10 \mu \mathrm{g} \mathrm{mL}^{-1} \mathrm{BPs}$ significantly reduced it. The maximum increase in $\mathrm{K}_{\mathrm{cat}}$ was observed at 36.15 and $23.06 \%$, respectively, at $150 \mu \mathrm{g} \mathrm{mL} \mathrm{L}^{-1} \mathrm{ZnO}-\mathrm{NPs}$ and BPs.

Ascorbate peroxidase. APX activity was evaluated as it catalyzes the hydrogen peroxide dependent oxidation of ascorbate in plants (Fig. 4a, Tables S1 and S2). Increasing ZnO-NPs levels from 10 to $150 \mu \mathrm{gL}^{-1}$, increased APX activity in pomegranate callus tissues, showing only 9.77 and $26.79 \%$ increases over untreated calli, respectively. However, ZnO-BPs inhibited the activity as indicated by 29.93 and $45.73 \%$ at 10 and $150 \mu \mathrm{g} \mathrm{mL} \mathrm{m}^{-1}$, respectively, relative to the controls. Moreover, under NPs treatments, APX activity showed a strong positive association with zinc concentration $\left(0.868^{\star \star}\right)$, while the same relationship was negatively strong in the case of BPs $\left(-0.826^{\star *}\right)$.

APX kinetic activity was affected differently by increasing the level of $\mathrm{ZnO}-\mathrm{NPs}$ or BPs in the nutrient medium (Fig. 4b, Table 1, Tables S7 and S8). The data revealed that no considerable changes were observed in the $\mathrm{K}_{\mathrm{m}}$ of APX enzyme in calli treated with ZnO-NPs. Moreover, NPs treatments reduced the $\mathrm{V}_{\max }$ of APX enzyme by $33.61 \%$ and $27.61 \%$ at 10 and $150 \mu \mathrm{g} \mathrm{mL} \mathrm{m}^{-1}$ respectively, compared to the controls. However, increased 


\begin{tabular}{|c|c|c|c|c|c|}
\hline Enzyme & $\begin{array}{l}\text { Trea } \\
(\mu \mathrm{g} n\end{array}$ & $\begin{array}{l}\text { nents } \\
\left.\mathrm{L}^{-1}\right)\end{array}$ & $\mathbf{K}_{\mathrm{m}}(\mu \mathrm{M})$ & 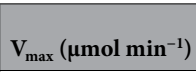 & $\mathbf{K}_{\text {cat }}\left(\mathbf{m i n}^{-1}\right)$ \\
\hline \multirow{5}{*}{ CAT } & 0 & 0 & $0.0076 \pm 0.0001 \mathrm{Cc}$ & $0.7512 \pm 0.0084 \mathrm{Aa}$ & $0.0276 \pm 0.0003 \mathrm{Bb}$ \\
\hline & \multirow{2}{*}{ NPs } & 10 & $0.0157 \pm 0.0002 \mathrm{~B}$ & $0.4011 \pm 0.0094 \mathrm{C}$ & $0.0260 \pm 0.0006 \mathrm{~B}$ \\
\hline & & 150 & $0.0264 \pm 0.0004 \mathrm{~A}$ & $0.6330 \pm 0.0262 B$ & $0.0377 \pm 0.0015 \mathrm{~A}$ \\
\hline & \multirow{2}{*}{ BPs } & 10 & $0.0115 \pm 0.0003 \mathrm{a}$ & $0.6074 \pm 0.0065 b$ & $0.0357 \pm 0.0003 \mathrm{a}$ \\
\hline & & 150 & $0.0099 \pm 0.0003 \mathrm{~b}$ & $0.7293 \pm 0.0193 a$ & $0.0367 \pm 0.0009 a$ \\
\hline \multirow{5}{*}{ POD } & 0 & 0 & $0.1052 \pm 0.0008 \mathrm{Ab}$ & $0.2391 \pm 0.0021 \mathrm{Aa}$ & $0.0088 \pm 0.0001 \mathrm{Cb}$ \\
\hline & \multirow{2}{*}{ NPs } & 10 & $0.0388 \pm 0.0005 \mathrm{C}$ & $0.1595 \pm 0.0011 \mathrm{C}$ & $0.0103 \pm 0.0001 \mathrm{~B}$ \\
\hline & & 150 & $0.0630 \pm 0.0006 \mathrm{~B}$ & $0.2006 \pm 0.0010 \mathrm{~B}$ & $0.0120 \pm 0.0001 \mathrm{~A}$ \\
\hline & \multirow{2}{*}{ BPs } & 10 & $0.1086 \pm 0.0002 \mathrm{a}$ & $0.1412 \pm 0.0011 \mathrm{c}$ & $0.0080 \pm 0.0001 \mathrm{c}$ \\
\hline & & 150 & $0.0782 \pm 0.0016 \mathrm{c}$ & $0.2146 \pm 0.0025 b$ & $0.0108 \pm 0.0001 \mathrm{a}$ \\
\hline \multirow{5}{*}{ APX } & & 0 & $0.4328 \pm 0.0026 \mathrm{Bc}$ & $1.3014 \pm 0.0796 \mathrm{Ab}$ & $0.0478 \pm 0.0029 \mathrm{Bc}$ \\
\hline & \multirow{2}{*}{ NPs } & 10 & $0.4290 \pm 0.0015 \mathrm{~B}$ & $0.8640 \pm 0.00197 \mathrm{C}$ & $0.0560 \pm 0.0001 \mathrm{~A}$ \\
\hline & & 150 & $0.4415 \pm 0.0029 \mathrm{~A}$ & $0.9420 \pm 0.0036 \mathrm{~B}$ & $0.0562 \pm 0.0002 \mathrm{~A}$ \\
\hline & \multirow{2}{*}{ BPs } & 10 & $0.8293 \pm 0.0035 b$ & $1.2333 \pm 0.0048 b$ & $0.0726 \pm 0.0002 b$ \\
\hline & & 150 & $1.3792 \pm 0.0066 \mathrm{a}$ & $1.9756 \pm 0.0141 \mathrm{a}$ & $0.0995 \pm 0.0007 \mathrm{a}$ \\
\hline \multirow{5}{*}{ PAL } & & 0 & $0.0131 \pm 0.0002 \mathrm{Aa}$ & $0.2546 \pm 0.0036 \mathrm{Ac}$ & $0.0094 \pm 0.0001 \mathrm{Cc}$ \\
\hline & \multirow{2}{*}{ NPs } & 10 & $0.0056 \pm 0.0001 \mathrm{C}$ & $0.2326 \pm 0.0012 \mathrm{~B}$ & $0.0151 \pm 0.0001 \mathrm{~A}$ \\
\hline & & 150 & $0.0066 \pm 0.0001 \mathrm{~B}$ & $0.2236 \pm 0.0031 \mathrm{C}$ & $0.0133 \pm 0.0001 \mathrm{~B}$ \\
\hline & \multirow{2}{*}{ BPs } & 10 & $0.0047 \pm 0.0001 \mathrm{~b}$ & $0.3086 \pm 0.0007 b$ & $0.0182 \pm 0.0001 b$ \\
\hline & & 150 & $0.0026 \pm 0.0001 \mathrm{c}$ & $0.3783 \pm 0.0013 \mathrm{a}$ & $0.0191 \pm 0.0001 \mathrm{a}$ \\
\hline \multirow{5}{*}{$\mathrm{PPO}$} & & 0 & $0.3464 \pm 0.0049 \mathrm{Aa}$ & $0.3297 \pm 0.0048 \mathrm{Aa}$ & $0.0121 \pm 0.0001 \mathrm{Aa}$ \\
\hline & \multirow{2}{*}{ NPs } & 10 & $0.1384 \pm 0.0008 \mathrm{C}$ & $0.0634 \pm 0.0009 \mathrm{C}$ & $0.0041 \pm 0.0001 \mathrm{C}$ \\
\hline & & 150 & $0.1754 \pm 0.0007 \mathrm{~B}$ & $0.1248 \pm 0.0004 \mathrm{~B}$ & $0.0074 \pm 0.0001 \mathrm{~B}$ \\
\hline & \multirow{2}{*}{ BPs } & 10 & $0.3098 \pm 0.0024 \mathrm{c}$ & $0.1679 \pm 0.0064 c$ & $0.0099 \pm 0.0003 c$ \\
\hline & & 150 & $0.3298 \pm 0.0046 b$ & $0.2249 \pm 0.0026 b$ & $0.0113 \pm 0.0001 b$ \\
\hline
\end{tabular}

Table 1. Michael constant $\left(\mathrm{K}_{\mathrm{m}}\right)$, maximum activity $\left(\mathrm{V}_{\max }\right)$, and catalytic $\left(\mathrm{K}_{\mathrm{cat}}\right)$ of catalase $(\mathrm{CAT})$, peroxidase (POD), ascorbate peroxidase (APX), phenylalanine ammonia-lyase (PAL), and polyphenol oxidase (PPO) enzymes of Punica granatum calli under the influence of different concentrations of ZnO-NPs and BPs for 28 days. Data are means \pm SD $(n=4)$. The different letters, capital for NPs treatments and small for BPs, indicate statistically significant differences $(P \leq 0.05)$.
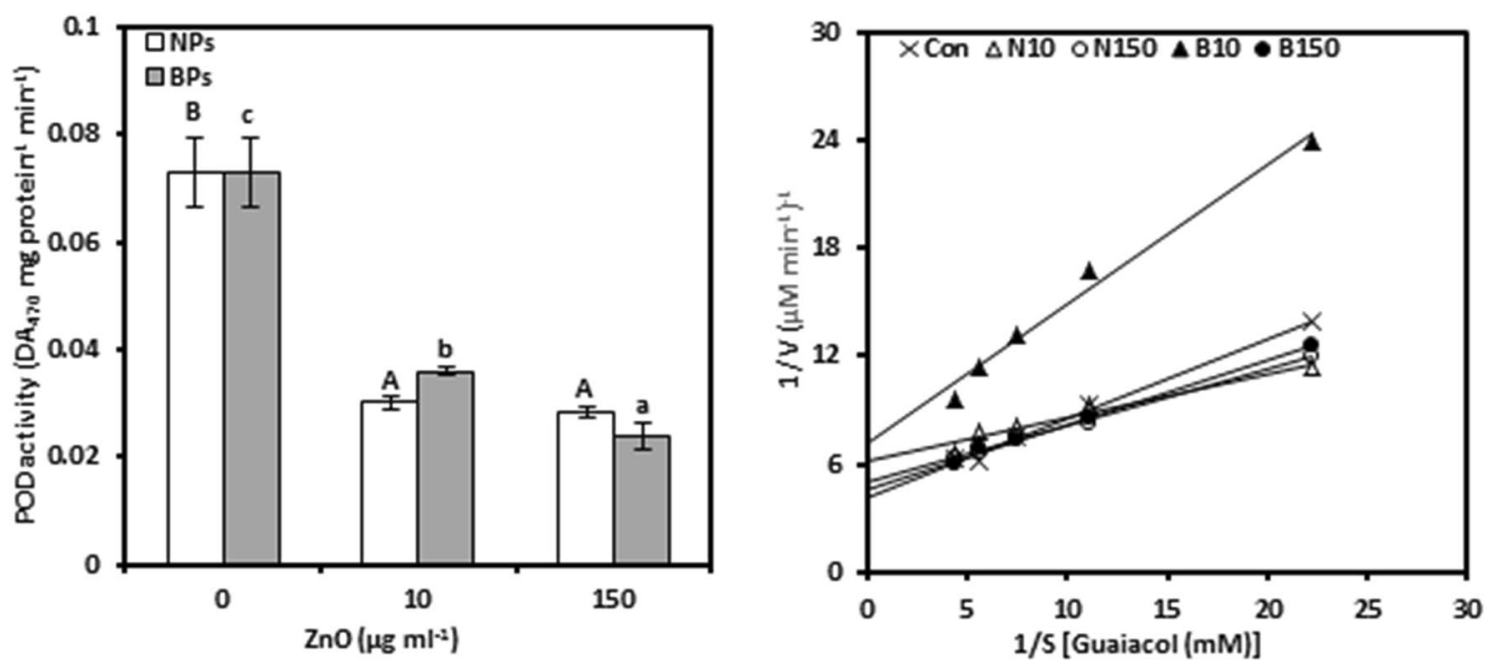

Figure 3. Peroxidase activity (POD; a) and Lineweaver-Burk curve of POD enzyme (b) of Punica granatum calli under the influence of different concentrations of ZnO-NPs and BPs for 28 days. Data are means \pm SD $(\mathrm{n}=4)$. The different letters, capital for NPs treatments and small for BPs, indicate statistically significant differences $(P \leq 0.05)$. 

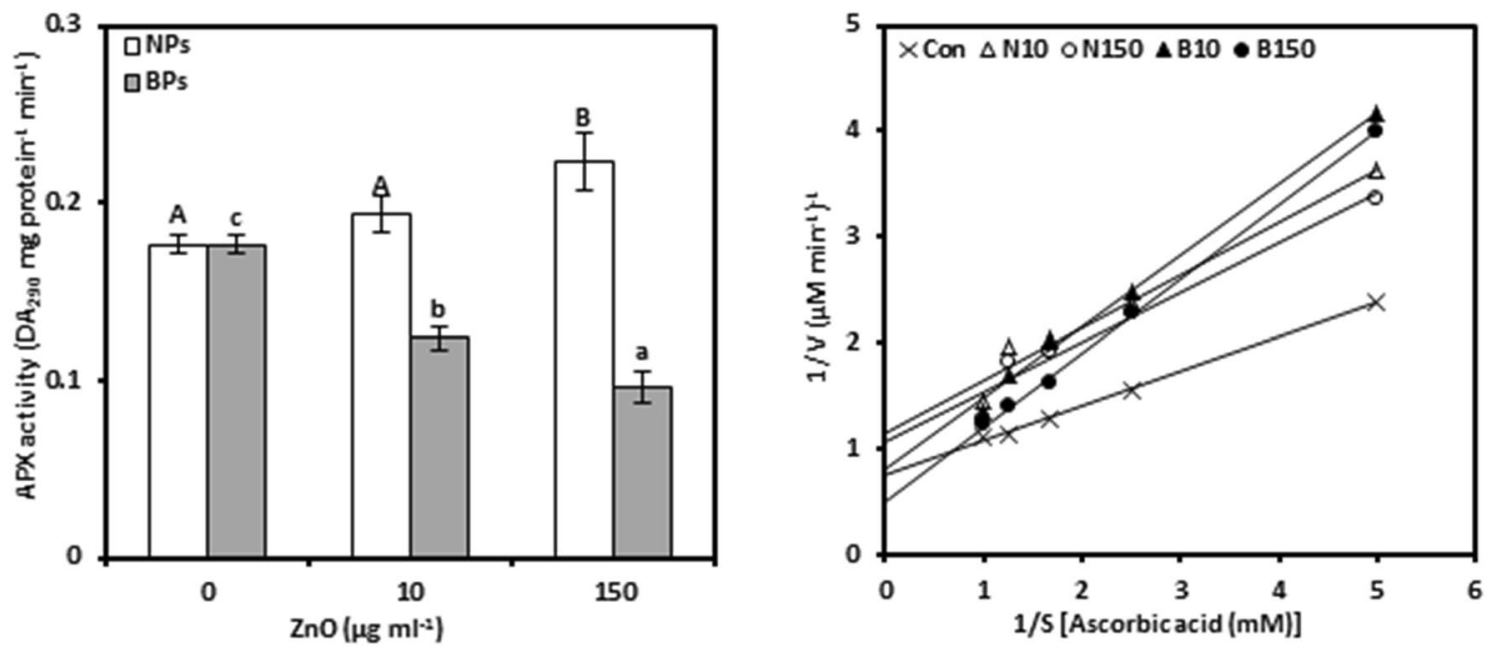

Figure 4. Ascorbate peroxidase activity (APX; a) and Lineweaver-Burk curve of APX enzyme (b) of Punica granatum calli under the influence of different concentrations of $\mathrm{ZnO}-\mathrm{NPs}$ and BPs for 28 days. Data are means \pm SD $(n=4)$. The different letters, capital for NPs treatments and small for BPs, indicate statistically significant differences $(P \leq 0.05)$.
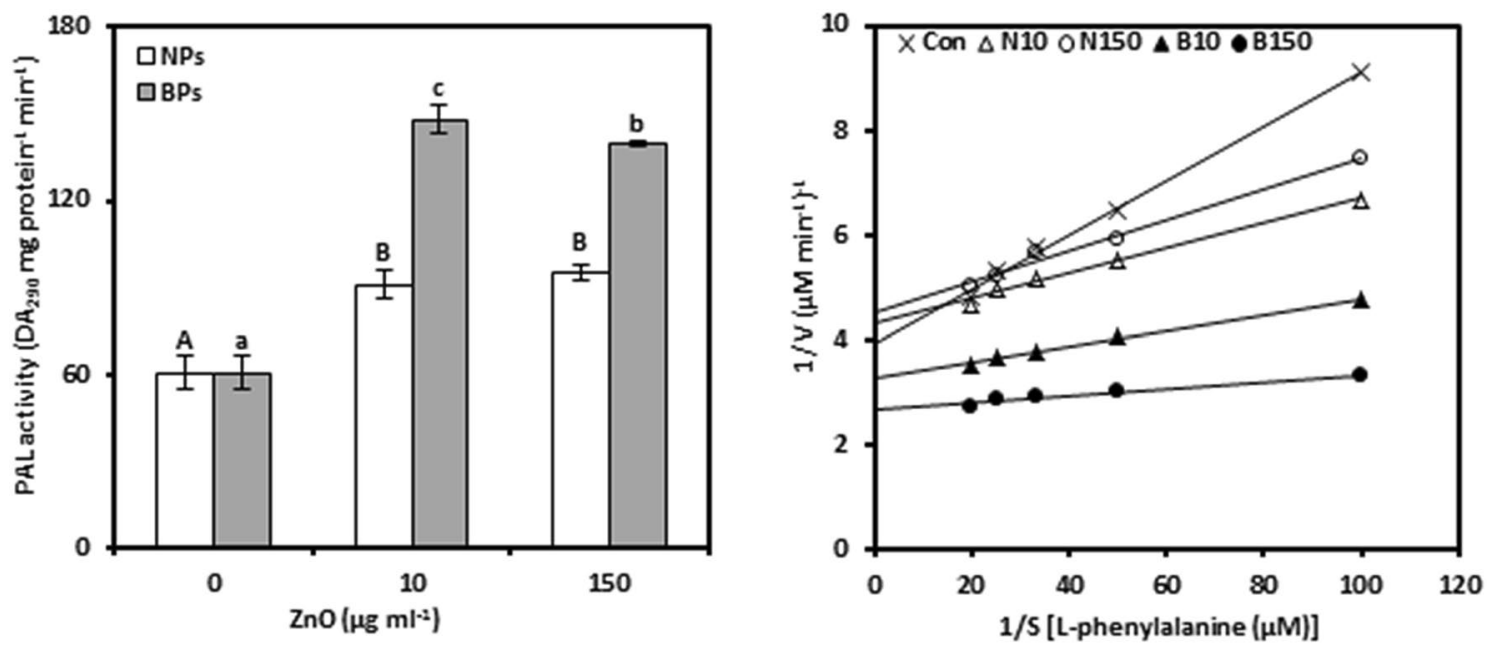

Figure 5. Phenylalanine ammonia-lyase activity (PAL; a) and Lineweaver-Burk curve of PAL enzyme (b) of Punica granatum calli under the influence of different concentrations of $\mathrm{ZnO}$-NPs and BPs for 28 days. Data are means $\pm S D(n=4)$. The different letters, capital for NPs treatments and small for BPs, indicate statistically significant differences $(P \leq 0.05)$.

concentrations of NPs stimulated the $\mathrm{K}_{\mathrm{cat}}$ of APX enzyme as shown by $17.09 \%$ and $17.46 \%$ at 10 and $150 \mu \mathrm{g} \mathrm{mL}$, respectively, over the control. Regarding $\mathrm{ZnO}-\mathrm{BPs}$, most $\mathrm{APX}$ kinetic parameters were increased with increasing concentration of BPs, only $\mathrm{V}_{\max }$ slightly decreased at $10 \mu \mathrm{g} \mathrm{mL} \mathrm{m}^{-1}$.

Phenylalanine ammonia-lyase. PAL was analyzed to mark whether $\mathrm{ZnO}-\mathrm{NPs}$ or $\mathrm{ZnO}$-BPs treatments affected phenolic biosynthesis in pomegranate calli (Fig. 5a, Tables S1 and S2). PAL activity, compared to the controls, was significantly increased in response to the concentrations of NPs (10 and $150 \mu \mathrm{g} \mathrm{mL} \mathrm{L}^{-1}$ ) by $49.82 \%$ and $56.95 \%$, respectively. A further increase in PAL activity was observed with increasing concentrations of BPs by $144.20 \%$ and $130.09 \%$, respectively, at 10 and $150 \mu \mathrm{g} \mathrm{mL} \mathrm{L}^{-1}$, above the controls. In addition, our results revealed that PAL activity under NPs (0.631) and BPs (0.573) represented an insignificant relationship with Zn content in callus tissues.

Compared to the control, treatments with $\mathrm{ZnO}$-NPs reduced $\mathrm{K}_{\mathrm{m}}$ and $\mathrm{V}_{\max }$ as indicated by a decrease of 49.64 and $12.17 \%$ at $150 \mu \mathrm{gL}^{-1}$, respectively (Fig. 5b, Table 1, Tables S9, 10). Similarly, a decrease in the $\mathrm{K}_{\mathrm{m}}$ of PAL enzyme was found in the $\mathrm{ZnO}$-BPs-treated callus; however, stimulation was observed in $\mathrm{V}_{\max }$. In contrast, treatments using $\mathrm{ZnO}-\mathrm{NPs}$ or BPs significantly increased the $\mathrm{K}_{\text {cat }}$ of PAL enzyme. BPs treatments showed a higher increase in $\mathrm{K}_{\text {cat }}$ of 94.15 and $103.69 \%$ of NPs resulting in increases of 61.14 and $42.51 \%$ at 10 and $150 \mu \mathrm{gL}^{-1}$, respectively, over the controls. 

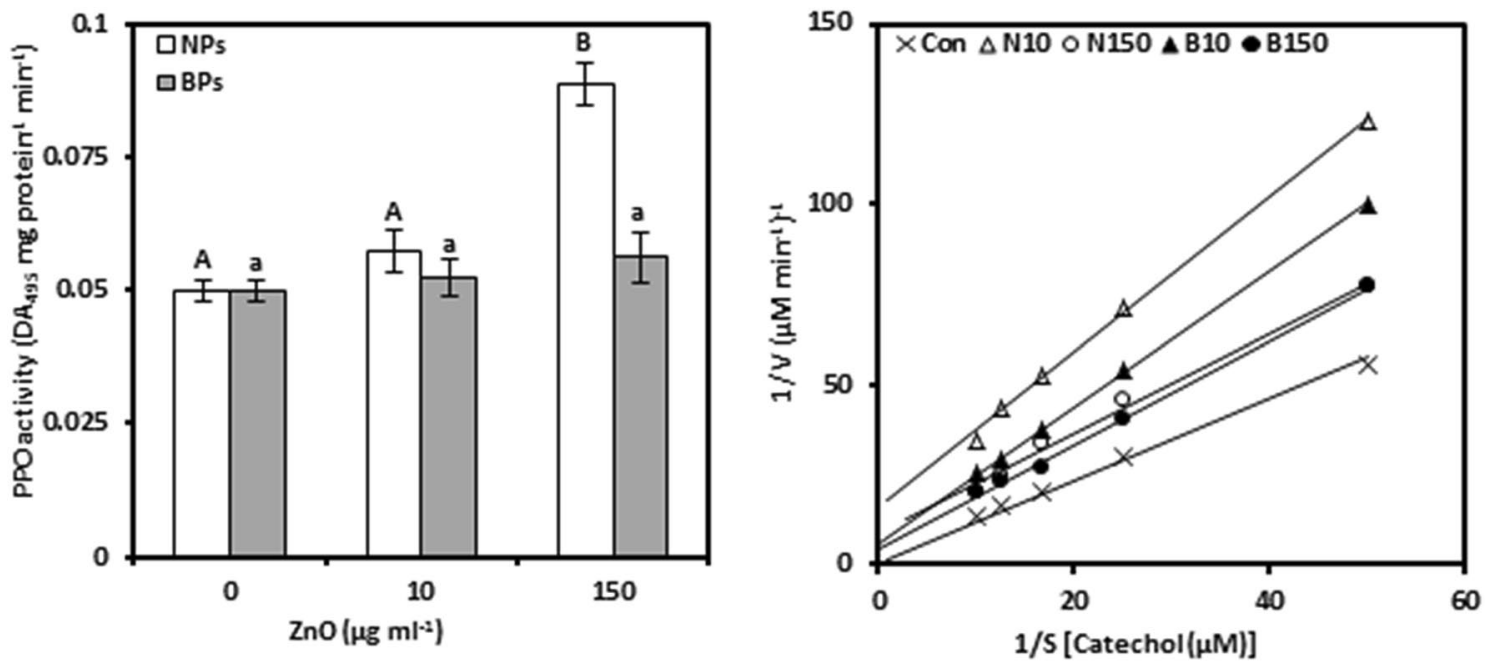

Figure 6. Polyphenol oxidase activity (PPO; a) and Lineweaver-Burk curve of PPO enzyme (b) of Punica granatum calli under the influence of different concentrations of $\mathrm{ZnO}-\mathrm{NPs}$ and BPs for 28 days. Data are means \pm SD $(n=4)$. The different letters, capital for NPs treatments and small for BPs, indicate statistically significant differences $(P \leq 0.05)$.

\begin{tabular}{|l|l|l|l|l|l|l|l|l|}
\hline \multicolumn{2}{|l|}{$\begin{array}{l}\text { Treatments } \\
\left(\mu \mathrm{g} \mathrm{mL} \mathbf{~ m}^{-1}\right)\end{array}$} & Zinc & Manganese & Iron & Copper & Potassium & Magnesium & Phosphorus \\
\hline \multirow{2}{*}{ NPs } & 0 & $1.786 \pm 0.055 \mathrm{C}$ & $0.540 \pm 0.030 \mathrm{C}$ & $25.560 \pm 0.362 \mathrm{~A}$ & $1.300 \pm 0.170 \mathrm{~A}$ & $8.098 \pm 0.620 \mathrm{~A}$ & $4.507 \pm 0.021 \mathrm{~A}$ & $205.864 \pm 23.04 \mathrm{~A}$ \\
\cline { 2 - 9 } & 10 & $2.677 \pm 0.025 \mathrm{~B}$ & $0.902 \pm 0.017 \mathrm{~B}$ & $14.515 \pm 0.100 \mathrm{~B}$ & $0.452 \pm 0.033 \mathrm{~B}$ & $6.883 \pm 0.748 \mathrm{~A}$ & $2.917 \pm 0.096 \mathrm{~B}$ & $240.076 \pm 20.86 \mathrm{~A}$ \\
\hline \multirow{2}{*}{$\mathrm{BPs}$} & 0 & $1.786 \pm 0.055 \mathrm{c}$ & $0.540 \pm 0.030 \mathrm{c}$ & $25.560 \pm 0.362 \mathrm{a}$ & $1.300 \pm 0.170 \mathrm{a}$ & $8.098 \pm 0.620 \mathrm{a}$ & $4.507 \pm 0.021 \mathrm{a}$ & $205.864 \pm 23.04 \mathrm{a}$ \\
\cline { 2 - 9 } & 10 & $2.422 \pm 0.036 \mathrm{~b}$ & $0.879 \pm 0.057 \mathrm{~b}$ & $24.138 \pm 1.029 \mathrm{a}$ & $0.599 \pm 0.010 \mathrm{~b}$ & $6.952 \pm 0.492 \mathrm{a}$ & $3.412 \pm 0.131 \mathrm{~b}$ & $212.934 \pm 6.44 \mathrm{a}$ \\
\hline
\end{tabular}

Table 2. Mineral concentrations of Punica granatum calli under the influence of different concentrations of $\mathrm{ZnO}-\mathrm{NPs}$ and BPs for 28 days. Data are means $\pm \mathrm{SD}(\mathrm{n}=4)$. The different letters, capital for NPs treatments and small for BPs, indicate statistically significant differences $(\mathrm{P} \leq 0.05)$.

Polyphenol oxidases. PPO activity was tested in pomegranate calli to consider at the degree of oxidation of phenolic compounds induced by ZnO-NPs or ZnO-BPs treatments (Fig. 6a, Tables S1, 2). PPO activity showed insignificant change in response to $10 \mu \mathrm{g} \mathrm{mL} \mathrm{mL}^{-1} \mathrm{ZnO}-\mathrm{NPs}$; however, it was $77.97 \%$ improved over the control value when exposed to $150 \mu \mathrm{g} \mathrm{mL}^{-1} \mathrm{ZnO}-\mathrm{NPs}$. Otherwise, no significant changes were observed in PPO activity by applying BPs to pomegranate calli. Moreover, the result showed strong positive correlations between PPO activity and $\mathrm{Zn}$ concentrations in the $\mathrm{ZnO}$-NPs- or BPs-treated callus $\left(0.979^{\star *}\right.$ and $0.949^{\star *}$, respectively).

The influence of NPs or BPs treatments on PPO kinetic activity of pomegranate calli was also studied (Fig. 6b, Table 1, Tables S11 and S12). All of the investigated kinetic parameters were reduced concerning PPO enzyme whatever of the concentration of NPs or BPs. Compared to the control, the highest reduction in $\mathrm{K}_{\mathrm{m}}$, $\mathrm{V}_{\max }$, and $\mathrm{K}_{\text {cat }}$ of PPO enzyme was found in $\mathrm{ZnO}-\mathrm{NPs}$ treatments to be $60.06 \%, 80.76 \%$, and $66.07 \%$ at $10 \mu \mathrm{g} \mathrm{mL} \mathrm{mL}^{-1}$, and $49.36 \%, 62.16 \%$, and $38.60 \%$ at $150 \mu \mathrm{g} \mathrm{m}^{-1}$, respectively. Likewise, exposure to BPs resulted in a statistically slight decrease in $\mathrm{K}_{\mathrm{m}}, \mathrm{V}_{\max }$, and $\mathrm{K}_{\mathrm{cat}}$ and the decrease, relative to the control, was $10.57 \%, 49.07 \%$, and $18.44 \%$ at $10 \mu \mathrm{g} \mathrm{mL} \mathrm{m}^{-1}$, and $4.79 \%, 31.77 \%$, and $6.48 \%$ at $150 \mu \mathrm{g} \mathrm{mL} \mathrm{m}^{-1}$, respectively.

Minerals. To determine whether $\mathrm{ZnO}$-NPs or $\mathrm{ZnO}$-BPs treatments affect the uptake of the macro-elements, $\mathrm{K}, \mathrm{Mg}$, and $\mathrm{P}$, these elements were analyzed in the tissues of pomegranate callus (Table 2, Tables S1, 2). Relative to the control, the different concentrations concerning NPs or BPs showed insignificant changes in the accumulation of $\mathrm{K}$ and $\mathrm{P}$ in callus tissues. Moreover, the data revealed non-significant correlations between $\mathrm{K}, \mathrm{P}$, and $\mathrm{Zn}$ concentrations in calli treated with $\mathrm{ZnO}-\mathrm{NPs}$ or BPs, only significant between $\mathrm{P}$ and $\mathrm{Zn}\left(0.766^{*}\right)$ under BPs conditions. The accumulation of $\mathrm{Mg}$ reduced with an increase in the level of NPs or BPs within the nutrient medium. Compared to the control, the largest decrease of $41.50 \%$ and $39.16 \%$, respectively, was observed in $\mathrm{Mg}$ accumulation at a concentration of $150 \mu \mathrm{g} \mathrm{mL} \mathrm{m}^{-1} \mathrm{ZnO}-\mathrm{NPs}$ or BPs. Moreover, ZnO-NPS or BPs treatments showed strong negative correlations between the $\mathrm{Mg}$ and $\mathrm{Zn}$ concentrations $\left(-0.737^{\star}\right.$ and $-0.890^{\star *}$, respectively).

In addition, the effect of NPs and BPs treatments on micronutrient accumulation in pomegranate callus was studied (Table 2, Tables S1, 2). Copper concentrations gradually reduced with increasing ZnO-NPs or BPs in the nutrient medium (relative to the control, $65.21 \%$, and $80.70 \%$ decreased for NPs, $53.92 \%$, and $67.58 \%$ for BPs at 

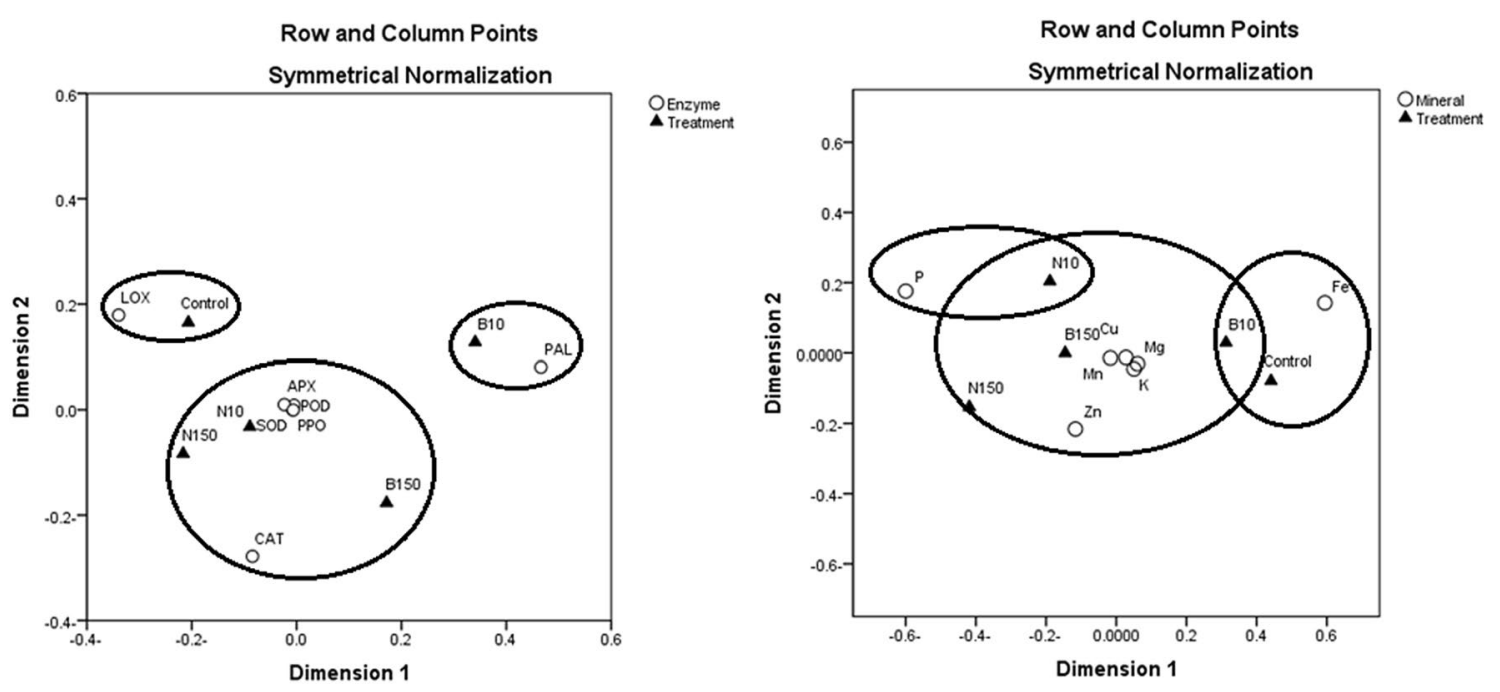

Figure 7. Correspondence analysis of redox-enzyme activities (a) and mineral concentrations (b) of Punica granatum calli under the influence of different concentrations of ZnO-NPs and BPs for 28 days. N10 and N150 $=\mathrm{ZnO}-\mathrm{NPs} 10$ and $150 \mu \mathrm{g} \mathrm{mL}^{-1}$; B10 and B150 = ZnO-BPs 10 and $150 \mu \mathrm{g} \mathrm{mL}^{-1}$; LOX = lipoxygenase; SOD = superoxide dismutase; $\mathrm{CAT}=$ catalase; $\mathrm{POD}=$ peroxidase; $\mathrm{APX}=$ ascorbate peroxidase; $\mathrm{PAL}=$ phenylalanine ammonia-lyase; $\mathrm{PPO}=$ polyphenol oxidase.

10 and $150 \mu \mathrm{g} \mathrm{mL} \mathrm{m}^{-1}$, respectively). Similarly, Fe concentration significantly decreased in callus tissues exposed to $\mathrm{ZnO}$-NPs (43.21\% and $70.17 \%$, at 10 and $150 \mu \mathrm{g} \mathrm{mL} \mathrm{mL}^{-1}$, respectively), while its concentration only decreased at $150 \mu \mathrm{g} \mathrm{mL} \mathrm{m}^{-1} \mathrm{ZnO}-\mathrm{BPs}(40.30 \%)$. In contrast, $\mathrm{Mn}$ concentration increased with increasing levels of NPs or BPs in the nutrient medium as evidenced by $66.86 \%, 62.68 \%, 140.61 \%$, and $138.00 \%$ at 10 and $150 \mu \mathrm{gL}^{-1}$ respectively, over the control. Further, the results showed that the $\mathrm{Cu}$ and $\mathrm{Fe}$ concentrations represented a strong negative association with the $\mathrm{Zn}$ concentration in NPs- or BPs-treated calli $\left(-0.754^{\star},-0.772^{\star},-0.883^{\star *}\right.$, and $-0.992^{\star *}$, respectively), whereas, the correlation was positive between $\mathrm{Mn}$ and $\mathrm{Zn}$ contents $\left(0.945^{\star *}\right.$ and $0.951^{\star *}$, respectively).

The uptake of zinc into the callus was dependent on the concentration and size of the particles (Table 2). As expected, the gradual increase in $\mathrm{ZnO}-\mathrm{NPs}$ or BPs treatments increased zinc accumulation in the callus tissues. The largest increase in $\mathrm{Zn}$ concentration was observed to be $279.23 \%$ within callus tissues exposed to $150 \mu \mathrm{g} \mathrm{mL}$ NPs, compared to BPs (171.52\%), over the control.

Correspondence analysis. Correspondence analysis confirmed strong correlations between the activities of CAT, SOD, POD, APX, PPO, and both levels of ZnO-NPs and the high level of ZnO-BPs (Fig. 7a,b). Moreover, it showed a close association between $\mathrm{K}, \mathrm{Mg}, \mathrm{Cu}, \mathrm{Mn}, \mathrm{Zn}, \mathrm{ZnO}-\mathrm{NPs}$, and BPs.

\section{Discussion}

Lipid decomposition and peroxidation of membrane-bound fatty acids under stress conditions are associated with elevated LOX activity ${ }^{38}$. Our results revealed that the high level of NPs boosted LOX activity, while the low level $\left(10 \mu \mathrm{gL}^{-1}\right)$, and both levels of BP failed to significantly boost its activity in the calli. These results indicate that callus tissues, exposed to the low level of $\mathrm{ZnO}-\mathrm{NPs}$ and both levels of $\mathrm{ZnO}$-BPs, may contain sufficient endogenous antioxidants to remove the low ROS content. Strong correlations between LOX activity and zinc concentration confirmed a previous review that $\mathrm{ZnO}-\mathrm{NPs}$ increase $\mathrm{O}_{2}{ }^{-}$formation, leading to oxidative stress $^{39}$. When $\mathrm{ZnO}-\mathrm{NPs}$ reach the mitochondria, they induce ROS by interfering with their reactions that lead to the depolarization of mitochondrial membranes ${ }^{40}$. The insignificant effects of these concentrations of NPs and BPs indicate that these treatments may not have highly toxic effects and that the antioxidant systems were able to detoxify ROS.

Several enzymatic antioxidants have been increased under $\mathrm{ZnO}-\mathrm{NPs}$ or BPs, indicating that these enzymes enable plants to withstand $\mathrm{ZnO}$ stress. SOD is a metallic enzyme ${ }^{41}$ that forms the primary line of protection against ROS; depending on the metal group, it is categorized into three main isozymes: Fe-SOD (found in plastids), MnSOD (found in mitochondria matrix, peroxisomes, cell wall), and $\mathrm{Cu} / \mathrm{Zn}$-SOD (found in cytosol, peroxisomes, and plastids) ${ }^{42}$. Statistics showed that ZnO-NPs or BPs stimulated SOD and CAT activities in callus tissues, indicating that $\mathrm{ZnO}$ catalyzed antioxidant enzymatic defense, which helped calli resisted this stress. Likewise, Zoufan et al. ${ }^{43}$ reported an increased SOD activity in leaves and roots of Chenopodium murale under the stress of $\mathrm{ZnO}-\mathrm{NPs}$. The SOD activity value, which decomposes $\mathrm{O}_{2}{ }^{-}$to $\mathrm{H}_{2} \mathrm{O}_{2}$, was changed to 1.7-fold higher in $\mathrm{ZnO}-\mathrm{NPs}$-treated calli, compared to 1.6 -fold in $150 \mu \mathrm{g} \mathrm{mL} \mathrm{L}^{-1} \mathrm{ZnO}-\mathrm{BPs}$. The elevated CAT activity, which degrades the $\mathrm{H}_{2} \mathrm{O}_{2}$ of the SOD product, in the callus tissues could indicate the callus tolerance of $\mathrm{ZnO}$ stress; as Stephenie et al. ${ }^{44}$ reported that elevated SOD activity, without the concomitant increase in $\mathrm{H}_{2} \mathrm{O}_{2}$ elimination capabilities, could lead to increased cytotoxicity. An increased SOD activity and $\mathrm{Mn}$ concentration with decreased $\mathrm{Cu}$ and Fe concentrations in callus tissues indicate an increased Mn-SOD isoenzyme activity. Likewise, the reduction 
in the available iron caused a shift to the use of the more available minerals, Mn, and as a result, Mn-SOD was second only to Fe-SOD ${ }^{45}$; the copper restriction also reduced the action of $\mathrm{Cu} / \mathrm{Zn}-\mathrm{SOD}^{46}$. Melchiorre et al. ${ }^{47}$ also found that higher Mn-SOD values were associated with tolerance to an abiotic stress in wheat. Our data displayed that CAT activity was significantly increased in $\mathrm{ZnO}$-treated calli, indicating that exposure to $\mathrm{ZnO}$ NPs or BPs increased ROS content in callus cells, but at the same time, they also catalyzed defense systems. A similar increase in CAT activity has been notified with the use of ZnO-NPs in mesquite plants ${ }^{48}$. Although the applications of NPs or BPs had a significant stimulatory effect on CAT activity, they reduced Fe accumulation in callus tissues. Santos et al. ${ }^{49}$ also declared that Fe deficiency increased CAT activity in inactive soybean strains. The strong correlation among CAT activity and $\mathrm{Zn}$ concentration may reveal that the CAT enzyme in calli is involved in antioxidant defense against $\mathrm{ZnO}$-NPs or BP stress. However, it was unlikely that NPs-treated callus could successfully remove ROS due to its low ability to remove $\mathrm{H}_{2} \mathrm{O}_{2}$ and $\mathrm{O}_{2}{ }^{-}$, resulting in a higher rate of the callus damage at high concentration $\left(150 \mu \mathrm{g} \mathrm{m}^{-1}\right)$ compared to $\mathrm{ZnO}$-BPs-treated callus. Consistent with these data, enhanced CAT activity was observed in mesquite seedlings ${ }^{48}$ and duckweed plants ${ }^{50}$ treated with $\mathrm{ZnO}-\mathrm{NPs}$. Strong positive correlations between CAT activity and manganese content in ZnO-NPs-treated calli $\left(0.947^{\star *}\right)$ or BPs $\left(0.921^{\star *}\right)$ confirm previous reports that the role of CAT in mitochondria is primarily correlated to the role of Mn-SOD in detoxification of mitochondria from ROS, which were generated during respiration of yeast ${ }^{51}$. Although the kinetic properties of redox-enzymes affected by heavy metals have been examined through numerous tests, the precise testing of the effects of $\mathrm{ZnO}-\mathrm{NPs}$ is yet deficient. Current results showed that, in the presence of NPs or BPs in the nutrient medium, an increase, decrease, or no change in the $\mathrm{K}_{\mathrm{m}}, \mathrm{V}_{\max }$, and $\mathrm{K}_{\mathrm{cat}}$ values of the redox-enzymes was obtained.

The $\mathrm{K}_{\mathrm{m}}$ is an important kinetics parameter of a simple test rate for the affinity of a substrate with an enzyme that can be demonstrated ${ }^{52}$. A new observation is that the $\mathrm{K}_{\mathrm{m}}\left(\mathrm{H}_{2} \mathrm{O}_{2}\right)$ of the CAT enzyme steadily increased as $\mathrm{ZnO}-\mathrm{NPs}$ or $\mathrm{ZnO}-\mathrm{BPs}$ increased. However, depending on the assumption that lower $\mathrm{K}_{\mathrm{m}}$ values are a characteristic of enzyme function that was valid only at low substrate concentrations ${ }^{53}$, the differences between $\mathrm{ZnO}-\mathrm{NPs}$ or $\mathrm{ZnO}-\mathrm{BPs}$ may be associated with increased calli growth in $\mathrm{ZnO}-\mathrm{BP}$. Rapid increases in the $\mathrm{K}_{\mathrm{m}}\left(\mathrm{H}_{2} \mathrm{O}_{2}\right)$ of the CAT enzyme in $\mathrm{ZnO}$-NPs or BPs-treated calli indicated that they are sensitive to $\mathrm{ZnO}$. Our results showed that the CAT enzyme from callus treated with $\mathrm{ZnO}$-BPs had a greater substrate affinity for $\mathrm{H}_{2} \mathrm{O}_{2}$ than that treated with $\mathrm{ZnO}$-NPs. They also showed that the CAT from callus treated with BPs had a greater substrate affinity for $\mathrm{H}_{2} \mathrm{O}_{2}$ than that treated with NPs. The plot displayed a set of straight lines revealing that the $\mathrm{V}_{\max }$ values were significantly decreased by $\mathrm{ZnO}-\mathrm{NPs}$ treatments, but in the case of $\mathrm{ZnO}-\mathrm{BPs}$ at $150 \mu \mathrm{g} \mathrm{mL} \mathrm{L}^{-1}$, the decrease was minimal. These results indicate that $\mathrm{ZnO}$ caused a mixed inhibition of the CAT enzyme, which indicate that $\mathrm{ZnO}$ could combine with the enzyme molecules additionally the enzyme-substrate-complex. The increase in $\mathrm{K}_{\mathrm{cat}}$ of CAT was confirmed in previous reports by Malanoski et al. ${ }^{54}$ who concluded that the ZnO-NPs-enzyme complexes did not depend on the shifting of products to the surface of $\mathrm{ZnO}$-NPs and the enzyme-complexes were directly influenced by $\mathrm{ZnO}-\mathrm{NPs}$ engagement.

Current data showed that with increased levels of NPs or BPs in the nutrient medium, POD activity decreased in pomegranate callus tissues, and these findings are consistent with earlier work that found adverse impacts of ZnONPs treatments on POD activity in purslane roots ${ }^{55}$. Unlike CAT activity, POD activity considerably decreased in NPs or BPs treated calli. Inhibition of POD and stimulation of CAT activity confirm earlier reports that concluded that the balance of antioxidant systems in plants could be delayed or modified to revoke oxidative stress $^{56}$. In addition, the obtained results indicated that CAT was negatively bound to Fe. However, the association between POD and Fe was positive under $\mathrm{ZnO}$-NPs or BPs. This association may be related to the higher ability of CAT to detoxify $\mathrm{H}_{2} \mathrm{O}_{2}$ compared to POD under Fe deficiency, which resulted from the interfering of $\mathrm{Zn}$ with Fe uptake. Moreover, it can be suggested that the decreased POD activity was due to iron deficiency, which is essential for the biosynthesis of this enzyme molecule.

Another new observation was that the decrease in $\mathrm{K}_{\mathrm{m}}$ and $\mathrm{V}_{\max }$ of POD by $\mathrm{ZnO}$-NPs treatments may be due to uncompetitive inhibition of ZnO-NPs. A similar effect was observed for ZnO-BPs at $150 \mu \mathrm{g} \mathrm{mL}^{-1} \mathrm{on} \mathrm{K}_{\mathrm{m}}$, $\mathrm{V}_{\mathrm{max}}$, and $\mathrm{K}_{\mathrm{cat}}$ in POD. These results may indicate that $\mathrm{ZnO}$ may combine with an enzymatic substrate complex. Although the enzyme had a high affinity for the substrates and the $\mathrm{K}_{\mathrm{cat}}$ was increased, the activity of this enzyme was low, and this may mean that the product interacts with $\mathrm{ZnO}$. However, $\mathrm{ZnO}$-BPs at the low level resulted in a corresponding increase in $\mathrm{K}_{\mathrm{m}}$ and a decrease in $\mathrm{V}_{\max }$ and $\mathrm{K}_{\mathrm{cat}}$ of POD, which may indicate that BPs at the low level had an affinity with the enzyme-substrate-compounds and enzymes.

Regarding ZnO-NPs, an increased APX activity was caused by an increased $\mathrm{H}_{2} \mathrm{O}_{2}$, suggesting that pomegranate callus might adapt to NPs through an effective defense system. Moreover, this increased activity could be maintained through a high AsA concentration, as was observed in the previous study in a ZnO-NPs-treated pomegranate callus ${ }^{4}$. Likewise, García-López et al. ${ }^{56}$ found that ZnO-NPs caused a concentration-dependent elevation in the APX activity of the Capsicum chinense plants. In contrast, APX inhibition was noticed in the $\mathrm{ZnO}$-BPs-treated callus. This shows that this enzyme may not be responsible for scavenging $\mathrm{H}_{2} \mathrm{O}_{2}$ in $\mathrm{ZnO}$-BPstreated calli or the $\mathrm{H}_{2} \mathrm{O}_{2}$ content associated with excess BPs was much less than that in the case of $\mathrm{ZnONPs}$ of callus cells. Accordingly, Wang et al. ${ }^{57}$ found that enhanced APX activity was noticed at low levels of $\mathrm{ZnO}$ (0.5-30 $\left.\mu \mathrm{g} \mathrm{mL}^{-1}\right)$; however, it was significantly reduced at higher levels. Furthermore, in ZnO-NPs treatments, strong positive and negative relations between APX activity, $\mathrm{Mn}$, and Fe, respectively, confirm that maintaining high levels of Mn may be required for AsA regeneration, and high levels of AsA may indicate an increased ROS production in iron-deprived callus tissues.

Moreover, it must be emphasized that at the low concentration of $\mathrm{ZnO}-\mathrm{NPs}$, an insignificant alter in $\mathrm{K}_{\mathrm{m}}$ and the decrease in $\mathrm{V}_{\max }$ of APX could result in the $\mathrm{ZnO}$-NPs binding to the site other than the substrate-binding site. Conversely, the increase in $\mathrm{K}_{\mathrm{cat}}$ and APX activity might indicate that the effect of $\mathrm{ZnO}-\mathrm{NPs}$ at low concentrations on the enzyme was less than the formation of products. For the higher concentration of $\mathrm{ZnO}-\mathrm{NPs}$, the 
increase in $\mathrm{K}_{\mathrm{m}}$ and the decrease in $\mathrm{V}_{\max }$ of APX could result from the binding of ZnO-NPs to both the enzyme and the enzyme-substrate complex.

Similar to the low level of $\mathrm{ZnO}-\mathrm{NPs}$, the increase in $\mathrm{K}_{\mathrm{cat}}$ can be suggested that the formation of the products was faster than the binding of $\mathrm{ZnO}$-NPs with the enzyme and the enzyme-substrate complex. In the case of $10 \mu \mathrm{g} \mathrm{mL}^{-1} \mathrm{ZnO}$-BPs, the increase in the $\mathrm{K}_{\mathrm{m}}$ value and an insignificant change in $\mathrm{V}_{\max }$ may reveal that $\mathrm{ZnO}$-BPs have an affinity for the active site of APX enzyme. The increase in the $\mathrm{K}_{\text {cat }}$ of APX enzyme under $10 \mu \mathrm{g} \mathrm{mL}^{-1}$ $\mathrm{ZnO}-\mathrm{BPs}$ despite decreased activity indicates reduced product dissociation from the enzyme-substrate complex ${ }^{54}$. The increase of $\mathrm{K}_{\mathrm{m}}, \mathrm{V}_{\max }$, and $\mathrm{K}_{\mathrm{cat}}$ of APX under $150 \mu \mathrm{g} \mathrm{mL} \mathrm{m}^{-1} \mathrm{ZnO}$-BPs indicate that the enzyme did not obey the Michaelis-Menten equation. These results indicate that $\mathrm{ZnO}$-BPs at the high-level bind to the regulatory site causing the inactive form and reducing APX enzyme activity.

In this experiment, $\mathrm{ZnO}$-NPs or $\mathrm{ZnO}$-BPs treatments stimulated the PAL activity in pomegranate callus tissues. This result indicated that the PAL enzyme participates in the synthesis of secondary metabolites by stimulating the phenylpropanoid pathway in pomegranate calli, supporting antioxidant systems in relation to increased ROS, and resistance of calli against Zn stress. Under ZnO-NPs or BPs treatments, the increase in the total phenolics content resulting from PAL activity can act as an electron transmitter that catalyzes the transfer of electrons to ROS in the antioxidant system ${ }^{4}$. In line with these results, stimulation of the effect of PAL was observed in two wheat cultivars (cultivar Kıraç-66 and T. durum Desf. Cv. Kızıltan-91) under zinc stress ${ }^{58}$. The strong positive correlation between the PAL activity and the Mn concentration and the negative relationship between PAL and Fe confirms previous reports of Engelsma ${ }^{59}$ and Dixon and Paiva ${ }^{60}$ who concluded that PAL activity was stimulated by the presence of $\mathrm{Mn}$ and Fe deficiency.

The $\mathrm{K}_{\mathrm{m}}$ and $\mathrm{V}_{\max }$ of PAL were reduced by treating the pomegranate callus with $\mathrm{ZnO}-\mathrm{NPs}$, but $\mathrm{K}_{\text {cat }}$ increased, indicating an uncompetitive type inhibition with faster dissociation of products than the binding of $\mathrm{ZnO}-\mathrm{NPs}$ to the enzyme-substrate complex. With regard to $\mathrm{ZnO}-\mathrm{BPs}$, the $\mathrm{K}_{\mathrm{m}}$ decreased with increasing concentrations of $\mathrm{ZnO}$-BPs, but $\mathrm{V}_{\max }$ increased. The Michaelis-Menten equation was not realized to describe the relation between substrates concentration and the initial velocity of the reaction in the existence of $\mathrm{ZnO}-\mathrm{BPs}^{21}$. An increase in $\mathrm{K}_{\mathrm{cat}}$ indicates that a higher concentration of the substrate may overcome enzyme inhibition.

The result showed that the high level of $\mathrm{ZnO}-\mathrm{NPs}$ significantly stimulated the PPO activity, while ZnO-BPs did not increase the activity significantly. This stimulation in PPO activity indicates that ZnO-NPs shift the callus metabolism toward the increased synthesis of phenolics, that was evident in our previous work ${ }^{4}$, and the activation of PPO; thus providing more antioxidants and defense against $\mathrm{ZnO}-\mathrm{NPs}$. Nonetheless, $\mathrm{ZnO}$-BPs had no impact on the PPO activity and it reveals that the ROS content associated with ZnO-BPs was not high enough to stimulate all defense agents. Moreover, the stimulation of PPO activity, despite the decrease in copper reveals that the copper content did not decrease to the level affecting PPO synthesis. Likewise, the induction of PPO activity was observed in Jatropha curcas treated with $300 \mu \mathrm{mol} \mathrm{L} \mathrm{L}^{-1} \mathrm{Zn}^{61}$.

A new observation was that under ZnO-NPs or BPs treatments, the reduction in $\mathrm{K}_{\mathrm{m}}, \mathrm{V}_{\mathrm{max}}$, and $\mathrm{K}_{\mathrm{cat}}$ of the $\mathrm{PPO}$ enzyme may result from uncompetitive inhibition of $\mathrm{ZnO}$. This finding indicates that $\mathrm{ZnO}-\mathrm{NPs}$ or BPs may have a significant affinity towards the enzyme-substrate complex. However, under ZnO-NPs treatments, the increase in the PPO activity indicates that the effects of $\mathrm{ZnO}-\mathrm{NPs}$ on product formation were greater than the interaction with the enzymatic substrate complex.

The entry of nanoparticles into plants is related to the zeta potential, and size ${ }^{62}$ that is able to enter from the apoplast and move to other parts via plasmodesmata ${ }^{63}$. ZnO-NPs or BPs treatments caused higher $\mathrm{Zn}$ concentrations in the pomegranate callus tissues, compared to controls, which mainly accumulated at $150 \mu \mathrm{g} \mathrm{mL}^{-1}$ of NPs approximately 1.1-fold higher than $\mathrm{ZnO}$-BPs and confirmed that their uptake was obviously related to size and levels. These findings were also noted in previous investigations ${ }^{64}$, which indicated that small NPs produce new root openings due to their high surface interaction, causing an increased mineral flux.

Excess $\mathrm{Zn}$ may interfere with the absorption of other elements within pomegranate callus. ZnO-NPs or BPs treatments reduced the $\mathrm{Cu}, \mathrm{Fe}$, and the $\mathrm{Mg}$ content in callus tissues; whereas, it did not affect the $\mathrm{K}$ and $\mathrm{P}$ concentration. However, for $\mathrm{Mn}$, an opposite position was observed, as it was increased with increasing concentrations of $\mathrm{ZnO}-\mathrm{NPs}$ or BPs. These results indicate that zinc is transported along the symplastic-pathway and competes with copper, iron, and magnesium for similar transporters. In contrast, K, P, and Mn were absorbed in other ways that did not directly interfere with zinc. This suggestion was confirmed by the insignificant correlation between the $\mathrm{K}$ and $\mathrm{Zn}$ concentration in $\mathrm{ZnO}-\mathrm{NPs}$ or BPs-treated calli. Thus, the present result is consistent with the previous results, which concluded that excess zinc had a more severe effect on micro-elements than on macro-nutrients in Arabidopsis ${ }^{65}$. Although the balance between zinc and phosphorus is related, and a decrease or increase of one element affects the other; however, with low zinc, there was an insignificant difference in the accumulation of phosphate transporter 1 transcripts of highly affinity phosphorus transporters within Arabidopsis roots ${ }^{66}$. The increase in manganese content was in line with earlier findings ${ }^{67}$. According to the negative strong correlations between the $\mathrm{Mn}$ and Fe contents under $\mathrm{ZnO}$-NPs or BPs treatments, we speculated that the increase in Mn due to a decrease in Fe and their competition for the iron-had regulated transporter $1^{68}$.

Our results revealed that the activities of CAT, SOD, POD, APX, and PPO were associated with levels of $\mathrm{ZnO}-\mathrm{NPs}$ and the high level of $\mathrm{ZnO}-\mathrm{BPs}$. These results indicate that the low level of $\mathrm{ZnO}$-BPs did not induce a high production of ROS to bind to these enzymes, but that the high level of BPs and levels of NPs stimulated these enzymes to withstand $\mathrm{ZnO}$ stress. The macronutrients $\mathrm{K}, \mathrm{Mg}$, and the micronutrients $\mathrm{Cu}, \mathrm{Mn}$ were also linked with $\mathrm{ZnO}-\mathrm{NPs}$ and BPs. Moreover, the relationships between these nutrients indicate that zinc interferes with the uptake of these nutrients. 


\section{Conclusion}

Our results revealed that high doses of ZnO-NPs likely had the potential to enhance LOX, SOD, CAT, APX, PAL, and the PPO activity, but they reduced the POD activity. On the other hand, ZnO-BPs had no effect on LOX and PPO activity; whereas, they stimulated SOD, CAT, and PAL activity. When calli were exposed to ZnO-BPs, APX and POD activities decreased. Moreover, NPs resulted in mixed inhibition of both CAT and APX enzymes. Regarding BPs, they showed competitive inhibition of CAT, whereas APX and PAL enzymes did not undergo the Michael Menten equation. ZnO-NPs/BPs treatments may result from uncompetitive inhibition of POD, as well as product interaction with $\mathrm{ZnO}$. Additionally, the results appeared that NPs or BPs may have a greater affinity for the PPO enzyme-substrate complexes and that the effects of NPs on product formation were greater than the interaction with the substrate-enzyme complexes. The accumulation of $\mathrm{Zn}$ in calli was proportional to the concentration of $\mathrm{Zn}$ in the medium, and this accumulation was higher in calli treated with ZnO-NPs than that treated with ZnO-BPs, which confirms the higher toxicity of NPs compared to BPs. Applications of NPs or BPs reduced the $\mathrm{Cu}, \mathrm{Fe}$, and the $\mathrm{Mg}$ content in callus tissues; whereas, they did not affect the $\mathrm{K}$ and $\mathrm{P}$ concentration. These results indicate that zinc is transported by the symplastic-pathway and competes with copper, iron, and magnesium for similar carriers. Our data unequivocally display that a low level of ZnO-BPs did not lead to a higher ROS production, whereas a higher level of BPs and levels of NPs boosted ROS production and interfered with the uptake of important nutrients, leading to an increase in some redox-enzymes to withstand $\mathrm{ZnO}$ stress. Our work contributes to the understanding of the effects of $\mathrm{ZnO}-\mathrm{NPs}$ on the activities, the kinetics of redoxenzymes, and the interaction with nutrients, and additional testing is required.

Received: 13 February 2020; Accepted: 28 October 2020

Published online: 12 November 2020

\section{References}

1. Khan, M. N., Mobin, M., Abbas, Z. K., AlMutairi, K. A. \& Siddiqui, Z. H. Role of nanomaterials in plants under challenging environments. Plant Physiol. Biochem. 110, 194-209 (2017).

2. Vale, G. et al. Manufactured nanoparticles in the aquatic environment-biochemical responses on freshwater organisms: a critical overview. Aquat. Toxicol. 170, 162-174 (2016).

3. Lin, L. et al. Quantitative proteomic analysis to understand the mechanisms of zinc oxide nanoparticle toxicity to Daphnia pulex (Crustacea: Daphniidae): comparing with bulk zinc oxide and zinc salt. Environ. Sci. Technol. 53, 5436-5444 (2019).

4. Radi, A. A., Farghaly, F. A., Al-Kahtany, F. A. \& Hamada, A. M. Zinc oxide nanoparticles-mediated changes in ultrastructure and macromolecules of pomegranate callus cells. Plant Cell Tissue Organ Cult. 135, 247-261 (2018).

5. Sharma, P., Jha, A. B., Dubey, R. S. \& Pessarakli, M. Reactive oxygen species, oxidative damage, and antioxidative defense mechanism in plants under stressful conditions. J. Bot. 2012, 1-26 (2012).

6. Yahyaoui, A. et al. Assessment of exposure wheat Triticum aestivum L. to zinc oxide nanoparticles (ZnO): evaluation of oxidative damage. Studia Universitatis" Vasile Goldis" Arad Seria Stiintele Vietii Life Sciences Series 27, 271-280 (2017).

7. Chen, J. et al. Nitric oxide ameliorates zinc oxide nanoparticles-induced phytotoxicity in rice seedlings. J. Hazard Mater. 297, 173-182 (2015).

8. Zhang, R. et al. Phytotoxicity of ZnO nanoparticles and the released $\mathrm{Zn}$ (II) ion to corn (Zea mays L.) and cucumber (Cucumis sativus L.) during germination. Environ. Sci. Pollut. Res. Int. 22, 11109-11117 (2015).

9. Ma, H., Williams, P. L. \& Diamond, S. A. Ecotoxicity of manufactured ZnO nanoparticles-a review. Environ. Pollut. 172, 76-85 (2013).

10. Hajra, A. \& Mondal, N. K. Effects of $\mathrm{ZnO}$ and $\mathrm{TiO}_{2}$ nanoparticles on germination, biochemical and morphoanatomical attributes of Cicer arietinum L.. Energy Ecol. Environ. 2, 277-288 (2017).

11. Mohammadi, R., Maali-Amiri, R. \& Abbasi, A. Effect of $\mathrm{TiO}_{2}$ nanoparticles on the effects of nano $\mathrm{TiO}_{2}$ and nano aluminum on wheat 1635 chickpea response to cold stress. Biol. Trace Elem. Res. 152, 403-410 (2013).

12. Sagardoy, R., Morales, F., López-Millán, A.-F., Abadía, A. \& Abadía, J. Effects of zinc toxicity on sugar beet (Beta vulgaris L.) plants grown in hydroponics. Plant Biol. 11,339-350 (2009).

13. Brown, J. C. Effect of zinc stress on factors affecting iron uptake in navy bean. J. Plant Nutr. 1, 171-183 (1979).

14. Gill, S. S. \& Tuteja, N. Reactive oxygen species and antioxidant machinery in abiotic stress tolerance in crop plants. Plant Physiol. Biochem. 48, 909-930 (2010).

15. Young, I. S. \& Woodside, J. V. Antioxidants in health and disease. J. Clin. Pathol. 54, 176-186 (2001).

16. Wang, H. et al. Physiological effects of magnetite $\left(\mathrm{Fe}_{3} \mathrm{O}_{4}\right)$ nanoparticles on perennial ryegrass (Lolium perenne L.) and pumpkin (Cucurbita mixta) plants. Nanotoxicology 5, 30-42 (2011).

17. Das, K. \& Roychoudhury, A. Reactive oxygen species (ROS) and response of antioxidants as ROS-scavengers during environmental stress in plants. Front. Environ. Sci. 2, 53 (2014)

18. Sharma, A. et al. Response of phenylpropanoid pathway and the role of polyphenols in plants under abiotic stress. Molecules $\mathbf{2 4}$, 2452 (2019).

19. Mishra, B. \& Sangwan, N. S. Amelioration of cadmium stress in Withania somnifera by ROS management: active participation of primary and secondary metabolism. Plant Growth Regul. 87, 403-412 (2019).

20. Kováčik, J., Klejdus, B., Hedbavny, J., Štork, F. \& Bačkor, M. Comparison of cadmium and copper effect on phenolic metabolism, mineral nutrients and stress-related parameters in Matricaria chamomilla plants. Plant Soil 320, 231 (2009).

21. Yang, J., Cao, W. \& Rui, Y. Interactions between nanoparticles and plants: phytotoxicity and defense mechanisms. J. Plant Interact. 12, 158-169 (2017).

22. Adhami, V. M., Syed, D. N., Khan, N. \& Mukhtar, H. Dietary flavonoid fisetin: a novel dual inhibitor of PI3K/Akt and mTOR for prostate cancer management. Biochem. Pharmacol. 84, 1277-1281 (2012).

23. Lansky, E. P. \& Newman, R. A. Punica granatum (pomegranate) and its potential for prevention and treatment of inflammation and cancer. J. Ethnopharmacol. 109, 177-206 (2007).

24. Helaly, M. N., El-Metwally, M. A., El-Hoseiny, H., Omar, S. A. \& El-Sheery, N. I. Effect of nanoparticles on biological contamination of 'in vitro' cultures and organogenic regeneration of banana. Aust. J. Crop Sci. 8, 612 (2014).

25. Ivanov, Y. V., Savochkin, Y. V. \& Kuznetsov, V. V. Scots pine as a model plant for studying the mechanisms of conifers adaptation to heavy metal action: 2. functioning of antioxidant enzymes in pine seedlings under chronic zinc action. Russ. J. Plant Physiol. 59, 50-58 (2012).

26. Murashige, T. \& Skoog, F. A revised medium for rapid growth and bio assays with tobacco tissue cultures. Physiol. Plant. 15, 473-497 (1962). 
27. Patil, V. M., Dhande, G. A., Thigale, D. M. \& Rajput, J. C. Micropropagation of pomegranate (Punica granatum L.) 'Bhagava'cultivar from nodal explant. Afr. J. Biotechnol. 10, 18130-18136 (2011).

28. Bonyanpour, A. \& Khosh-Khui, M. Callus induction and plant regeneration in Punica Granatum L. "Nana" from leaf explants. J. Cent. Eur. Agric. 14, 75-83 (2013).

29. Lowry, O. H., Rosebrough, N. J., Farr, A. L. \& Randall, R. J. Protein measurement with the Folin phenol reagent. J. Biol. Chem. 193, 265-275 (1951).

30. Minguez-Mosquera, M. I., Jaren-Galan, M. \& Garrido-Fernandez, J. Lipoxygenase activity during pepper ripening and processing of paprika. Phytochemistry 32, 1103-1108 (1993).

31. Misra, H. P. \& Fridovich, I. The role of superoxide anion in the autoxidation of epinephrine and a simple assay for superoxide dismutase. J. Biol. Chem. 247, 3170-3175 (1972).

32. Aebi, H. Catalase in vitro. Method Enzymol. 105, 121-126 (1984).

33. Zaharieva, T., Yamashita, K. \& Matsumoto, H. Iron deficiency induced changes in ascorbate content and enzyme activities related to ascorbate metabolism in cucumber roots. Plant Cell Physiol. 40, 273-280 (1999).

34. Nakano, Y. \& Asada, K. Hydrogen peroxide is scavenged by ascorbate-specific peroxidase in spinach chloroplasts. Plant Cell Physiol. 22, 867-880 (1981).

35. Havir, E. A. \& Hanson, K. R. L-Phenylalanine ammonia-lyase. II. Mechanism and kinetic properties of the enzyme from potato tubers. Biochemistry 7, 1904-1914 (1968).

36. Kumar, K. B. \& Khan, P. A. Peroxidase and polyphenol oxidase in excised ragi (Eleusine corocana CV PR 202) leaves during senescence. Indian J. Exp. Biol. 20, 412-416 (1982).

37. Lineweaver, H. \& Burk, D. The determination of enzyme dissociation constants. J. Am. Chem. Soc. 56, 658-666 (1934).

38. Babenko, L. M., Shcherbatiuk, M. M., Skaterna, T. D. \& Kosakivska, I. V. Lipoxygenases and their metabolites in formation of plant stress tolerance. Ukr. Biochem. J. 89, 5-21 (2017).

39. Manke, A., Wang, L. \& Rojanasakul, Y. Mechanisms of nanoparticle-induced oxidative stress and toxicity. Biomed. Res. Int. 2013, $942916(2013)$

40. Xia, T. et al. Comparison of the abilities of ambient and manufactured nanoparticles to induce cellular toxicity according to an oxidative stress paradigm. Nano Lett. 6, 1794-1807 (2006).

41. Jackson, C. A., Moore, A. L., Halliwell, B., Foyer, C. H. \& Hall, D. O. Subcellular localization and identification of superoxide dismutase in the leaves of higher plants. Eur. J. Biochem. 91, 339-344 (1978).

42. Miller, A. F. Superoxide dismutases: Ancient enzymes and new insights. FEBS Lett. 586, 585-595 (2012).

43. Zoufan, P., Baroonian, M. \& Zargar, B. ZnO nanoparticles-induced oxidative stress in Chenopodium murale L., Zn uptake, and accumulation under hydroponic culture. Environ. Sci. Pollut. Res. 27, 11066-11078 (2020).

44. Stephenie, S., Chang, Y. P., Gnanasekaran, A., Esa, N. M. \& Gnanaraj, C. An insight on superoxide dismutase (SOD) from plants for mammalian health enhancement. J. Funct. 68, 103917 (2020).

45. Alscher, R. G., Erturk, N. \& Heath, L. S. Role of superoxide dismutases (SODs) in controlling oxidative stress in plants. J. Exp. Bot. 53, 1331-1341 (2002).

46. Cohu, C. M. \& Pilon, M. Regulation of superoxide dismutase expression by copper availability. Physiol. Plant. 129, 747-755 (2007).

47. Melchiorre, M., Robert, G., Thippi, V., Racca, R. \& Lascano, H. R. Superoxide dismutase and glutathione reductase overexpression in wheat protoplast: photooxidation stress tolerance and change in cellular redox state. Plant Growth Regul. 57, 57-68 (2009).

48. Hernandez-Viezcas, J. A., Castillo-Michel, H., Servin, A. D., Peralta-Videa, J. R. \& Gardea-Torresdey, J. L. Spectroscopic verification of zinc absorption and distribution in the desert plant Prosopis juliflora-velutina (velvet mesquite) treated with $\mathrm{ZnO}$ nanoparticles. Chem. Eng. J. 170, 346-352 (2011).

49. Santos, C. S. et al. Understanding the role of the antioxidant system and the tetrapyrrole cycle in iron deficiency chlorosis. Plants 8, 348 (2019).

50. Hu, C., Liu, Y., Li, X. \& Li, M. Biochemical responses of duckweed (Spirodela polyrhiza) to zinc oxide nanoparticles. Arch. Environ. Contam. Toxicol. 64, 643 (2013).

51. Petrova, V. Y., Rasheva, T. V. \& Kujumdzieva, A. V. Catalase enzyme in mitochondria of Saccharomyces cerevisiae. Electron. J. Biotechnol. 5, 1-13 (2002).

52. Shen, S., Li, X. F., Cullen, W. R., Weinfeld, M. \& Le, X. C. Arsenic binding to proteins. Chem. Rev. 113, 7769-7792 (2013).

53. Griffith, S. M., Brewer, T. G. \& Steiner, J. J. Thermal dependence of the apparent $\mathrm{K}_{\mathrm{m}}$ of glutathione reductase from three wetland grasses and maize. Ann. Bot. 87, 599-603 (2001).

54. Malanoski, A. P. et al. Kinetic enhancement in high-activity enzyme complexes attached to nanoparticles. Nanoscale Horiz. 2, 241-252 (2017).

55. Iziy, E., Majd, A., Vaezi-Kakhki, M. R., Nejadsattari, T. \& Noureini, S. K. Effects of zinc oxide nanoparticles on enzymatic and nonenzymatic antioxidant content, germination, and biochemical and ultrastructural cell characteristics of Portulaca oleracea $\mathrm{L}$. Acta Soc. Bot. Pol. 88, 3639 (2019).

56. García-López, J. I. et al. Zinc oxide nanoparticles boosts phenolic compounds and antioxidant activity of Capsicum annuum L. during germination. Agronomy 8, 215 (2018).

57. Wang, C. et al. The effect of excess $\mathrm{Zn}$ on mineral nutrition and antioxidative response in rapeseed seedlings. Chemosphere 75, 1468-1476 (2009).

58. Koç, E., İşlek, C. \& Büyükkartal, H. N. Comparison of phenylalanine ammonia lyase response to lead and zinc stress in different wheat genotypes. Communications faculty of sciences. Univ, Ankara Ser. C 27, 37-44 (2018).

59. Engelsma, G. A possible role of divalent manganese ions in the photoinduction of phenylalanine ammonia-lyase. Plant Physiol. 50, 599-602 (1972).

60. Dixon, R. A. \& Paiva, N. L. Stress-induced phenylpropanoid metabolism. Plant Cell 7, 1085-1097 (1995).

61. Marques, M. C., Nascimento, C. W. A., da Silva, A. J. \& Gouveia-Neto, A. Tolerance of an energy crop (Jatropha curcas L.) to zinc and lead assessed by chlorophyll fluorescence and enzyme activity. S. Afr. J. Bot. 112, 275-282 (2017).

62. Wong, M. H. et al. Lipid exchange envelope penetration (LEEP) of nanoparticles for plant engineering: a universal localization mechanism. Nano Lett. 16, 1161-1172 (2016).

63. Rico, C. M., Majumdar, S., Duarte-Gardea, M., Peralta-Videa, J. R. \& Gardea-Torresdey, J. L. Interaction of nanoparticles with edible plants and their possible implications in the food chain. J. Agric. Food Chem. 59, 3485-3498 (2011).

64. Castiglione, M. R., Giorgetti, L., Geri, C. \& Cremonini, R. The effects of nano- $\mathrm{TiO}_{2}$ on seed germination, development and mitosis of root tip cells of Vicia narbonensis L. and Zea mays L.. J. Nanopart. Res. 13, 2443-2449 (2011).

65. Jain, A. et al. Commentary: the materials project: a materials genome approach to accelerating materials innovation. APL Mater. 1, 011002 (2013).

66. Khan, G. A. et al. Coordination between zinc and phosphate homeostasis involves the transcription factor PHR1, the phosphate exporter PHO1, and its homologue PHO1;H3 in Arabidopsis. J. Exp. Bot. 65, 871-884 (2014).

67. Venkatesan, S., Hemalatha, K. V. \& Jayaganesh, S. Characterization of manganese toxicity and its influence on nutrient uptake, antioxidant enzymes and biochemical parameters in tea. Res. J. Phytochem. 1, 52-60 (2007).

68. Connolly, E. L., Fett, J. P. \& Guerinot, M. L. Expression of the IRT1 metal transporter is controlled by metals at the levels of transcript and protein accumulation. Plant Cell 14, 1347-1357 (2002). 


\section{Acknowledgements}

This work was carried out in the Genetic Engineering and Tissue Culture Research Unit at Assiut University. The authors thank Dr. Mokhtar Mamdouh Shaaban and all members of the unit for sharing experiences in the field of tissue culture. The authors thank Dr. Saber Galal, Faculty of Education, Assiut University, for the English language corrections.

\section{Author contributions}

F.F., A.R., and A.H. conceived and designed the research. F.F., A.R., and F.A. conducted experiments. F.F., A.R., F.A., and A.H. analyzed the data and wrote the manuscript. All authors read and approved the manuscript.

\section{Funding}

This research did not receive any specific grant from funding agencies in the public, commercial, or non-profit sectors. This manuscript has got Springer Nature APC Waiver.

\section{Competing interests}

The authors declare no competing interests.

\section{Additional information}

Supplementary information is available for this paper at https://doi.org/10.1038/s41598-020-76664-4.

Correspondence and requests for materials should be addressed to A.M.H.

Reprints and permissions information is available at www.nature.com/reprints.

Publisher's note Springer Nature remains neutral with regard to jurisdictional claims in published maps and institutional affiliations.

(c) Open Access This article is licensed under a Creative Commons Attribution 4.0 International License, which permits use, sharing, adaptation, distribution and reproduction in any medium or format, as long as you give appropriate credit to the original author(s) and the source, provide a link to the Creative Commons licence, and indicate if changes were made. The images or other third party material in this article are included in the article's Creative Commons licence, unless indicated otherwise in a credit line to the material. If material is not included in the article's Creative Commons licence and your intended use is not permitted by statutory regulation or exceeds the permitted use, you will need to obtain permission directly from the copyright holder. To view a copy of this licence, visit http://creativecommons.org/licenses/by/4.0/.

(c) The Author(s) 2020 